\title{
Linking bioavailability and toxicity changes of complex chemicals mixture to support decision making for remediation endpoint of contaminated soils
}

Cipullo S. ${ }^{1}$, Negrin I. ${ }^{1}$, Claveau L. ${ }^{1}$, Snapir B. ${ }^{1}$, Tardif, S. ${ }^{2}$, Pulleyblank C. ${ }^{1,3}$, Prpich G. ${ }^{4}$, Campo P. ${ }^{1}$, Coulon F. ${ }^{1 *}$

${ }^{1}$ Cranfield University, School of Water, Energy and Environment, Cranfield, MK43 0AL, UK

${ }^{2}$ University of Copenhagen, Department of Plant and Environmental Sciences Microbial Ecology and Biotechnology, Denmark

${ }^{3}$ Dublin City University, School of Chemical Sciences, Glasnevin, Dublin 9, Ireland

${ }^{4}$ University of Virginia, Department of Chemical Engineering, United States of America

*Corresponding author: f.coulon@cranfield.ac.uk, +44 (0)1234 754981

\section{Abstract}

A six-month laboratory scale study was carried out to investigate the effect of biochar and compost amendments on complex chemical mixtures of tar, heavy metals and metalloids in two genuine contaminated soils. An integrated approach, where organic and inorganic contaminants bioavailability and distribution changes, along with a range of microbiological indicators and ecotoxicological bioassays, was used to provide multiple lines of evidence to support the risk characterisation and assess the remediation end-point. Both compost and biochar amendment $(\mathrm{p}=$ $0.005)$ as well as incubation time $(\mathrm{p}=0.001)$ significantly affected the total and bioavailable concentrations of the total petroleum hydrocarbons (TPH) in the two soils. Specifically, TPH concentration decreased by $46 \%$ and $30 \%$ in Soil 1 and Soil 2 amended with compost. These decreases were accompanied by a reduction of 78\% (Soil 1) and $6 \%$ (Soil 2) of the bioavailable hydrocarbons and the most significant decrease was observed for the medium to long chain aliphatic compounds $\left(\mathrm{EC}_{16-35}\right)$ and medium molecular weight aromatic compounds $\left(\mathrm{EC}_{16-21}\right)$. Compost amendment enhanced the degradation of both the aliphatic and aromatic fractions in the two soils, while biochar contributed to lock the hydrocarbons in the contaminated soils. Neither compost nor biochar affected the distribution and behaviour of the heavy metals (HM) and metalloids in the different soil phases, suggesting that the co-presence of heavy metals and metalloids posed a low risk. Strong negative correlations were observed between the bioavailable hydrocarbon fractions and the ecotoxicological assays suggesting that when bioavailable concentrations decreased, the toxicity also 
decreased. This study showed that adopting a combined diagnostic approach can significantly help to identify optimal remediation strategies and contribute to change the over-conservative nature of the current risk assessments thus reducing the costs associated with remediation endpoint.

Keywords : Contaminated soils, Mixtures, Bioavailability, Toxicity, Bioremediation

\section{Introduction}

Anthropogenic activities are the main cause of release of potentially toxic compounds in soil, among which heavy metals, metalloids and petroleum hydrocarbon products are the ones mostly found at contaminated sites (Hou and Al-tabbaa, 2014). Remediation approaches at contaminated sites are promising strategies to mitigate the risks posed by the pollutants; in particular bio-stimulation and bio-addition are common practices aiming at improving soil quality; adding organic matter, delivering nutrients, balancing $\mathrm{pH}$, and increasing water holding capacity, thus enhancing the degradation process (Wang et al., 2017). Commonly used amendment for soil remediation include composted agricultural by-products and coal combustion products (e.g biochars) (U.S. Environmental Protection Agency, 2007), which have been widely studied due to their sustainable, efficient, and cost-effective approach (Ahmad et al., 2014). Compost amendment is a common remediation strategy where organic materials, such as manure or decomposed organic matter, are added to contaminated soil to stimulate soil microorganisms and thus promoting transformation of hydrocarbons into less toxic compounds (Davie-Martin et al., 2017). Apart from providing a carbon source for the existing pool of bacteria, compost addition can also introduce new microorganisms presenting different catabolic activities that could potentially enhance the remediation of polluted soils (Baldantoni et al., 2017). Another common amendment strategy, is adding biochar, a carbon-rich material obtained from the decomposition of biomass in absence (or low exposure) of oxygen (Liu et al., 2015). Due to its highly porous structure and alkaline nature, biochar is able to immobilise soil contaminants, hence its frequent usage in soil remediation (Egene et al., 2018). When added to the soil, biochar causes the release of carbonates, phosphates, and hydroxyl ions because of its alkaline $\mathrm{pH}$ value of $7-10$, thus 
favouring metal stabilisation. Both electrostatic (surface adsorption) and non-electrostatic (functional groups complexation) interactions are responsible for a decrease in metals mobility and bioavailability (Van Poucke et al., 2018).

While organic amendment have been shown to effectively improve degradation of pollutants in soil, remediation success has often been defined by reduction of total contaminant concentration (Kuppusamy et al., 2017) rather than bioavailable concentrations. However, the extent to which contaminants are bioavailable has significant implications for the clean-up targets and risk assessment, as receptors respond to the fraction of contaminant that is bioavailable rather than the total fraction (National Research Council, 2003). Bioavailability, the freely available fraction of contaminants in soil (Semple et al., 2003), is nowadays regarded as an important feature to integrate in risk assessment as it can help to explain contaminants partitioning and degradation in the environment (Ortega-Calvo et al., 2015). In this regard, soil bioassays have been largely used to determine the ecological effects of complex chemicals or mixtures in environmental samples, since they provide a rapid characterization of the contaminants' bioavailable fraction (Mazzeo et al., 2014).

There is a need to find a pragmatic and practical integrated approach where biological and chemical measures of bioavailability are correlated rather than developed independently, supporting the necessity of several lines of evidence for robust and informed risk assessment (British Standards Institution, 2017). Ecotoxicological methods along with bioavailability have the potential to offer a cost-saving approach to contaminated land by applying relatively cheap bioassays to evaluate the potential effects of contaminants of concern, and to demonstrate that a contaminated site may not require further actions (Kim et al., 2014; Sarsby and Meggyes, 2009; Udovic et al., 2013). However, the majority of these approaches focus often on single contaminant rather than mixtures. Thus, assessing and implementing bioavailability of complex chemical mixtures in order to reduce conservativisms of the traditional chemical-based approach, remains a challenge (Cachada et al., 2016; Kienzler et al., 2016). 
Therefore in the present study, we investigated the effect of soil amendments (compost or biochar) on the behaviour and bioavailability of a complex tar mixture containing aromatics, aliphatics, heavy metals, and metalloids. This work aim at assessing the relevance of a different range of biological indicators to understand the implications for risk assessment and identifying the end-point remediation. Moreover, bioavailability-proxy and the toxicity data were further correlated to provide the necessary evidence that these tools may be suitable for predicting site-specific bioavailability of complex chemical mixtures.

\section{Materials and methods}

\subsection{Sample collection and physico-chemical characterisation}

Two soils were collected from two UK brownfield sites occupied by former gasworks in Kent $\left(51^{\circ}\right.$ 18' 39" N $0^{\circ} 43^{\prime} 17^{\prime \prime}$ E, Soil 1) and Northamptonshire ((52²0' 23" N $0^{\circ} 39^{\prime} 17^{\prime \prime} \mathrm{W}$, Soil 2). Prior analysis, soil samples were homogenised through $2 \mathrm{~mm}$ - sieve to separate large particles such as plant parts (roots, stems, and leaves), cobbles and pebbles. Each soil samples was divided and processed for analysis, individual air-dried samples were used for: Soil $\mathrm{pH}$ analysis $(10 \mathrm{~mL})$, particle size distribution (10 mL), loss of ignition (5 g), Total Nitrogen (TN) and Total Carbon (TC) (0.001 mg), Total Phosphorous (TP) and available phosphorous (AP) (5 g). Additionally, fresh soil samples were used for dry matter and water content analysis $(5 \mathrm{~g})$.

$\mathrm{TN}$ and TC in soil material were determined by combustion at approximately $900^{\circ} \mathrm{C}$ in the presence of oxygen; the amount of nitrogen and carbon was then measured by a thermal conductivity detector (TCD) (BS EN 13654-2, 2001) using vario EL III Element Analyzer (elementar Analysensysteme GmbH,DE). Total phosphorous was measured with a hydrochloric/nitric acid mixture extraction and the phosphorus content was determined by a spectrometric measurement in solution (ISO 11047:1998) with a Spectronic Helios Gamma (Thermo Electron Corporation,UK). Available phosphorous was measured by treating the soil with a $0.5 \mathrm{~mol} / \mathrm{L}$ sodium hydrogen carbonate solution at $\mathrm{pH} 8.5$, the extract was then analysed by spectrometry (ISO 11263, 1994). Ammonium-N, nitrate- 
$\mathrm{N}$ and were extracted from soil using a $2 \mathrm{~mol} / \mathrm{L}$ solution of potassium chloride, the extract was analysed by spectrometry (Method 53 of the MAFF Reference Book RB427 1986).

Dry matter and water content in soil samples were measured by drying at $105^{\circ} \mathrm{C} \pm 5^{\circ} \mathrm{C}$ for $24 \mathrm{~h}$. The difference in mass of an amount of soil before and after the drying procedure was used to calculate the dry matter and water contents on a mass basis (ISO 11465, 1993). Soil pH was measured (Jenway $3540 \mathrm{pH} /$ Conductivity Meter, Keison Products,UK) with 1 part of soil per 5 parts of water after shaking for $60 \mathrm{~min}$ and subsequent equilibration period of $30 \mathrm{~min}$ (ISO 10390, 2005). The soil organic content was determined by loss of ignition (LOI): air-dried soil was dehydrated at $105^{\circ} \mathrm{C}$ for $24 \mathrm{~h}$ then ashed at $450{ }^{\circ} \mathrm{C}$ for $5 \mathrm{~h}$ and ignition loss was expressed as a percentage of the dehydrated sample (BS EN 13039, 2000). Particle size distribution was determined by the sieving and sedimentation method. In short, soil organic matter was decomposed with hydrogen peroxide and the resulting slurry dispersed with a buffered sodium hexametaphosphate solution, then the different particle size fractions were determined by a combination of sieving and sedimentation (ISO 11277, 2009). The corresponding soil texture classes were identified by using a soil texture calculato (Natural England Technical Information Note TIN037, 2008). To obtain the mass fraction, the compost and biochar samples were oven dried at $60^{\circ} \mathrm{C}$ for 24 hours to remove any residual water absorbed during storage (López et al., 2002). The samples were then sieved using a series of five sieves with mesh widths of $20 \mathrm{~mm}, 10 \mathrm{~mm}$, coarse $(0.6-2 \mathrm{~mm})$, medium $(0.2-0.6 \mathrm{~mm})$, and fine $(0.06-0.2 \mathrm{~mm})$. The contribution of each mass fraction was expressed as percentage of the total.

\subsection{Mesocosms experimental design}

For each soil, duplicate mesocosms (i.e. 10-L polypropylene buckets) containing $5 \mathrm{~kg}$ of soil amended either with $15 \%$ w/w compost (Soil + Compost), with $5 \%$ w/w biochar (Soil + Biochar), or without amendment (Soil) were prepared. The biochar used in this study was a commercial enriched biochar purchased from Carbon Gold (UK). The $5 \%$ biochar to soil ratio was selected, as it is often reported 
as the most efficient application rate to reduce leachable contaminant concentrations in contaminated soils. For instance, in these studies, biochar was applied (loading rates at 5\% w/w) and significantly reduced bioavailability (T. Wang et al., 2017) and leachability of HM concentrations, for both genuinely contaminated (Novak et al., 2018) and spiked (Park and Choppala, 2011) soils. . Compost used in this study was multi-purpose enriched peat-based compost with nutrients purchased from Westland Horticulture Ltd (UK). Similarly, $15 \%$ compost to soil ratio was selected as a best criteria based on previous studies (Adams et al., 2015; Singh and Ward, 2004; Speight and El-Gendy, 2017; Taccari et al., 2012).

All the mesocosms were manually mixed to obtain homogenous samples and stored outdoor for the whole duration of the experiment. Samples were collected from each mesocosm at 0, 30, 90 and 180 days for chemical, microbiological, and toxicological analysis. All samples were collected randomly by disturbing the top $30 \mathrm{~cm}$ of the mesocosm's content and immediately stored at $4^{\circ} \mathrm{C}$ to minimise biological transformation or other chemical reactions. Biological and ecotoxicological analyses were always carried out within 3 days of sampling.

\subsection{Chemical analysis}

\subsubsection{Total and bioavailable hydrocarbon extraction}

A modification of the method reported by Risdon et al. (2008) was used to determine total, readilyavailable, and bioavailable petroleum hydrocarbons including both aliphatic and aromatic fractions (See Table 1 for the fractions and TPH). Briefly, $2.5 \mathrm{~g}$ of soil were mixed with either (i) $15 \mathrm{~mL}$ of $1: 1$ dichloromethane:hexane, (ii) $15 \mathrm{~mL}$ of methanol, or (iii) $20 \mathrm{~mL}$ of $4: 1$ mixture of hydroxypropyl- $\beta$ cyclodextrin (HP- $\beta-\mathrm{CD})$ :water solution to extract the total, readily-available, and bioavailable petroleum hydrocarbons content, respectively. For the estimation of the total and readily-available hydrocarbon content, the samples were sonicated (Ultrasonic Bath, U2500H, Ultrawave (UW), UK) for $20 \mathrm{~min}$ at room temperature, and shaken at $150 \mathrm{rpm}$ (Multi Reax Shaker, Heidolph Instruments $\mathrm{GmbH} \& \mathrm{CO} . \mathrm{KG}$ ) for $16 \mathrm{~h}$. On the following day, samples were again sonicated for $20 \mathrm{~min}$ at room 
temperature and centrifuged (2000 g for $10 \mathrm{~min}$ ) (Thermo Scientific ${ }^{\mathrm{TM}}$, Sorvall ${ }^{\mathrm{TM}}$ ST 40 Centrifuge Series). The supernatant was then cleaned onto a $6 \mathrm{~mL}$ SPE DSC-Si silica tubes. From the $10 \mathrm{~mL}$, $0.5 \mathrm{~mL}$ of sample was taken and mixed with $0.5 \mathrm{~mL}$ of internal standards comprised of a deuterated alkanes mix (C10 ${ }^{\mathrm{d} 22}, \mathrm{C} 19^{\mathrm{d} 40}$ and $\left.\mathrm{C} 30^{\mathrm{d} 62}\right)$ and deuterated polycyclic aromatic hydrocarbons (PAH) mix (1,4-dichlorobenzene ${ }^{\mathrm{d} 4}$, naphthalene ${ }^{\mathrm{d} 8}$, anthracene ${ }^{\mathrm{d} 10}$, chrysene ${ }^{\mathrm{d} 12}$ and perylene ${ }^{\mathrm{d} 12}$ ) at $10 \mu \mathrm{g}$ $\mathrm{mL}^{-1}$ each, respectively.

For the estimation of the bioavailable hydrocarbon content, samples were mixed with HP- $\beta$-CD : water solution according to Reid (2000). Following $20 \mathrm{~h}$ mixing, the sample was centrifuged at 2000 $\mathrm{g}$ for $30 \mathrm{~min}$. The supernatant was discarded and the soil pellets were resuspended in 1:1 dichloromethane: hexane (exhaustive solvent extraction) to assess the residual amount of organic compound as described by Risdon et al. (2008). The compounds uptaken by the cyclodextrin molecule was then measured subtracting the residual amount of organic compound extracted by dichloromethane: hexane after the initial HP- $\beta-C D$ wash, against the total amount extracted by dichloromethane: hexane (Papadopoulos et al., 2007).

Concentration of petroleum hydrocarbons were identified and quantified by gas chromatographymass spectrometry (GC-MS) using an Agilent gas chromatograph coupled to a Turbomass Gold mass spectrometer operated at $70 \mathrm{eV}$ in positive ion mode. The column used was a Restek fused silica capillary column $(30$ x $0.25 \mathrm{~mm}$ internal diameter $)$ coated with RTX ${ }^{\circledR}-5 \mathrm{MS}(0.25 \mu \mathrm{m}$ film thickness). Splitless injection with a sample volume of $1 \mu 1$ was applied. The oven temperature was increased from $60{ }^{\circ} \mathrm{C}$ to $220^{\circ} \mathrm{C}$ at $20{ }^{\circ} \mathrm{C} \min ^{-1}$ then to $310{ }^{\circ} \mathrm{C}$ at $6{ }^{\circ} \mathrm{C} \min ^{-1}$ and held at this temperature for 15 min; for a total run time of $38 \mathrm{~min}$. The mass spectrometer was operated using the full scan mode (range m/z 50-500) for quantitative analysis of target aliphatic and aromatic hydrocarbons. For each compound, quantification was performed by integrating the peak at specific $m / z$. External multilevel calibrations were carried out using alkane (standard solution $\left(\mathrm{C}_{8}-\mathrm{C}_{40}\right)$ Sigma Aldrich, Dorset, UK) and PAH (EPA 525 PAH Mix A; Sigma Aldrich, Dorset, UK) standards, the concentration of which ranged from 2.5 to $50 \mu \mathrm{g} \mathrm{mL}^{-1}$ respectively. For quality control, blank controls and a $500 \mu \mathrm{g} \mathrm{mL} \mathrm{L}^{-1}$ 
diesel standard solution (ASTM $\mathrm{C}_{12}-\mathrm{C}_{60}$ quantitative, Supelco) were analyzed every 20 samples. The variation of the reproducibility of extraction and quantification of soil samples were determined by successive injections $(n=7)$ of the same sample and estimated to $\pm 8 \%$. In addition, duplicate reagent control and reference material were systematically used. The reagent control was treated following the same procedure as the samples without adding soil sample. The reference material was an uncontaminated soil of known characteristics, and was spiked with a diesel and mineral oil standard at a concentration equivalent to $16,000 \mathrm{mg} \mathrm{kg}^{-1}$. Relative standard deviation (RSD) values for all the soils was $<10 \%$.

\subsubsection{Pseudo-total metal and CISED sequential extractions}

Pseudo-total metal digestion was performed according to the ISO 11047 method with aqua regia (ISO 11047, 1998). Briefly, $0.5 \mathrm{~g}$ of air-dried and $2 \mathrm{~mm}$ sieve soil was extracted with $8 \mathrm{~mL}$ hydrochloric/nitric acid mixture in a microwave digestion system (Multiwave 3000 microwave oven, Anton Paar/ Perkin Elmer, UK). The extract was then filtered through $0.45 \mu$ m nylon syringe filters and diluted to $50 \mathrm{~mL}$ with DI water.

A modification of the method reported by Cave et.al (2004) was used for the sequential extraction; approximately $2 \mathrm{~g}$ of soil was consecutively extracted each time with $10 \mathrm{~mL}$ of solutions with increasing concentrations of nitric acid from ( 0 to $5 \mathrm{M}$ ) and $\mathrm{H}_{2} \mathrm{O}_{2}$ (Cipullo et al., 2018).

All pseudo-total and sequential extracts were diluted 4 times with $1 \% \mathrm{HNO}_{3}$ before analysis using a NexION® 350D ICP-MS (Perkin Elmer) calibrated with a mixture of both major (Ca, Fe, $\mathrm{K}, \mathrm{Mg}$, $\mathrm{Mn}, \mathrm{Na}, \mathrm{S}, \mathrm{Si}, \mathrm{P}$ ) and trace (Al, As, Ba, Cd, Co, Cr, Cu, Hg, Li, Mo, Ni, Pb, Sb, Se, Sr, V, Zn) elements ranging between 1 and $40 \mu \mathrm{g} \mathrm{mL}^{-1}$ and 0.01 and $2 \mu \mathrm{g} \mathrm{mL} \mathrm{m}^{-1}$, respectively. In both cases, working standards were prepared in matching sample matrix solutions (nitric acid 1\%). Calibration standards and samples extracts were spiked with the following mix of four internal standards: Sc, Ge, $\mathrm{Rh}$, and Bi. ICP-MS was calibrated after each sample (14 sequential extracts) and the limit of detection was defined as concentration three times larger than the standard deviation of the acid blank. 
Additionally, acid blanks (1 \% nitric acid), digestion blank, and guidance materials (BGS 102$)$ were analysed every batch of 7 samples along with an adequate rinse time programmed in between samples; to monitor blank contamination, sensitivity, operating conditions, and extraction's accuracy. Mean repeatability of $\mathrm{BGS}_{102}$ (expressed as relative standard deviation \%) was lower than 6 and $8 \%$ for sequential and aqua regia digestion respectively. All elements' concentrations have been converted into $\mathrm{mg} / \mathrm{kg}$ extracted from the soil-solid matrix.

Data obtained from sequential extraction were used in a chemometric self-modelling algorithm known as the Chemometric Identification of Substrates and Element Distributions (CISED). The CISED was performed with MatLab (Version R2015a, 8.5.0.197613, 64-bit, Academic Licence) following the protocol developed by Cave et al. (2004) and Denys et al. (2012), and was used to derive information on the partitioning and bioavailable concentrations of HM and metalloids in soil. The self-modelling mixture resolution (SMMR) algorithm produced three key outputs (1) profile output: contains the modelled soil component with similar physical-chemical properties (mg/kg), (2) distribution output: contains the concentration of each element across the identified soil components (mg/kg), (3) composition output: contains element concentration the identified component (expressed as percentage).

Modelled soil components and element distribution data, obtained from the MatLab algorithm, have been post-processed in RStudio (Version 1.1.423 - (C) 2009-2018 RStudio, Inc.) to create a matrix, which has been further categorised using a clustering methodology, and visualised in a heatmap as previously described by Wragg et al., (2014) and Cox et al., (2013) (Supplelementary information Figure $3 \mathrm{~A}$ and $\mathrm{B})$.

Both profile and clustering outputs were then used to calculate HM/metalloids concentration and distribution in: (1) pore water fraction (HM/metalloids easily extractable with DI water, 0.01 and 0.05 M nitric acid, therefore highly mobile and potentially bioavailable (Giller et al., 2009; Ogundiran and Osibanjo, 2009), (2) exchangeable fraction (HM/metalloids associated with carbonates that can become available with time (Karbassi and Shankar, 2005; Sundaray et al., 2011), and (3) non- 
exchangeable fraction (HM/metalloids bounded with oxides) therefore non-available and unlikely to pose risk for receptors (Hodson et al., 2011; Kim et al., 2015) (Supplelementary information Figure 4).

\subsection{Microbiological analysis}

\subsubsection{Determination of total bacteria count}

Determination of culturable bacteria was performed according to Coulon et al. (2010). Briefly, $1 \mathrm{~g}$ of soil was weighed into a 50-mL centrifuge tube and $10 \mathrm{~mL}$ of Ringer's solution (1/4 strength) added. Tubes were then vortexed for $30 \mathrm{~s}$ and sonicated twice for $30 \mathrm{~s}$ and allowed to stand for a further 2 min. A 1-mL aliquot of soil suspension was removed and serially diluted in Ringer's solution to the appropriate dilution factor $\left(10^{-6}\right)$. An aliquot sample of $100 \mu \mathrm{L}$ of each dilution series was added in triplicate to Tryptone Soya Agar (TSA) medium for incubation at $25{ }^{\circ} \mathrm{C}$ for $24-48 \mathrm{~h}$. Subsequently, colony-forming units (CFU) were enumerated.

\subsubsection{Basal respiration}

Two replicates $(5 \mathrm{~g})$ of each soil were placed in a $24 \mathrm{~mL}$ sterilised vial and sealed. An empty vial, with an ambient air sample from the laboratory was taken and analysed to account for background conditions. Vials were left to equilibrate for $5 \mathrm{~h}$, incubated for $24 \mathrm{~h}$ at $20{ }^{\circ} \mathrm{C}$, and the headspace analysed for $\mathrm{CO}_{2}$ content (Paton et al., 2006). The composition of the headspace produced was recorded by CSi 200 Series GC (Cambridge Scientific Instruments Ltd., Witchford, UK), using helium as carrier gas at $20 \mathrm{psi}(138 \mathrm{kPa})$. The Gas Chromatography with Thermal Conductivity Detector (GC-TCD) was equipped with a CTR1 concentric packed column (Alltech, USA). The column oven and injector temperature were $110{ }^{\circ} \mathrm{C}$ and $125^{\circ} \mathrm{C}$, respectively. The instrument was calibrated with $\mathrm{CO}_{2}$ calibration standards ( $\mathrm{STG}$ of $\mathrm{Calgaz}^{\mathrm{TM}}$, UK) () in the range $1-5 \% \mathrm{CO}_{2}$ balanced with $\mathrm{N}_{2}$. 


\subsubsection{Phospholipid Fatty Acid Analysis (PLFA)}

Phospholipid fatty acid (PLFA) analysis was used to identify and assess the community structure as reported by Frostegård et al. (1993). Phospholipids in approximately $7 \mathrm{~g}$ of freeze dried soil (Christ Alpha 1-2 LDplus $-55^{\circ} \mathrm{C}$ Freeze Dryer) were extracted with chloroform, methanol and citrate buffer (1:2:0.8 by volume), separated by solid-phase extraction and then derivatised by mild alkaline methanolysis. Fatty acid methyl esters were analysed by Gas Chromatography with Flame Ionisation Detector (GC-FID) (Agilent Technologies 6890N) fitted with a HP-5 (Agilent Technologies) fused silica capillary column ( $30 \mathrm{~m}$ length, $0.32 \mathrm{~mm} \mathrm{ID}, 0.25 \mu \mathrm{m}$ film). Helium was used as a carrier gas at $1 \mathrm{~mL} \mathrm{~min}{ }^{-1}$ flow rate. The initial oven temperature was $50{ }^{\circ} \mathrm{C}$ hold for $1 \mathrm{~min}$ (splitless mode) and subsequently ramped to $160{ }^{\circ} \mathrm{C}$ at $25^{\circ} \mathrm{C} / \mathrm{min}, 240{ }^{\circ} \mathrm{C}$ at $2{ }^{\circ} \mathrm{C} / \mathrm{min}$ and $310{ }^{\circ} \mathrm{C}$ at $25^{\circ} \mathrm{C} / \mathrm{min}$. Three injection volumes were $1 \mu \mathrm{L}$ and the injector temperature was set at $310{ }^{\circ} \mathrm{C}$. A total of 34 different PLFA were detected according to Pawlett et al., (2013) and Tunlid (1992). The relative abundance of individual PLFA was expressed as a percentage of the total of the target responses of all identified PLFA peaks and calculated from the subtraction between peak response of the sample and blank (solvent) response. PLFA containing fewer than 14 or more than 20 carbons were excluded, as this range is considered to be typical of microbial cellular membranes from the domains of bacteria and fungi (Quideau et al., 2016).

\subsection{Ecotoxicological bioassays}

\subsubsection{Seeds germination assay}

Mustard (B. alba), rye grass (L. perenne), and pea (P. sativum) species were used in the seed germination assays (Dawson et al., 2007). Five mustard, five rye grass, and three pea seeds were added separately in glass jars (triplicates) containing $20 \mathrm{~g}$ of soil re-wetted to $70 \%$ moisture. Lids were loosely screwed on to reduce evaporation but allowing aeration. Seeds were left to germinate in a controlled temperature chamber in the dark at $25{ }^{\circ} \mathrm{C}$ and $70 \%$ humidity. A clean uncontaminated soil (control) was used to take into account the germination rate of the seeds. Germination incidence 
of above $90 \%$ was recorded in the uncontaminated soil for all seeds at all sampling times over the experimental period. When $>70 \%$ seeds in the uncontaminated soil germinated, the number of seeds germinated in all soil samples was recorded; this was after 4, 6 or 7 days exposure.

\subsubsection{Earthworms acute toxicity assay}

Tiger worm (E. fetida) was used to assess lethality and sub-lethal effects in earthworm acute toxicity assay. Adult worms, maintained in uncontaminated compost, weighing between 0.5 and $1.5 \mathrm{~g}$ were washed in tap water and depuriated overnight. Individual earthworms were placed in a pot containing $50 \mathrm{~g}$ of soil re-wetted to $70 \%$ moisture (Dawson et al., 2007). Five replicates were used for each soil sample. Lids were screwed onto the pot and perforated to allow aeration, but prevent water loss and worm escape. Pots were incubated at room temperature for $14 \mathrm{~d}$. Specimens were examined on days 3,7 , and 14 for lethality and assigned a score $(0,1$, or 2$)$ from a Condition Index (CI) (Langdon et al., 1999). To assess sub-lethal effects worms were again washed with tap water on day 14, reweighed on day 15 and the change in weight calculated.

\subsubsection{Microtox ${ }^{\circledR}$ Basic Solid Phase Test}

Each of the soil samples (Soil, Soil + Compost, and Soil + Biochar) were collected at 0, 30, 90, and 180 days and used to evaluate soil toxicity to bioluminescent bacteria (Vibrio fischeri) with Microtox ${ }^{\circledR}$ assay (Modern Water). The Basic Solid Phase Test procedure (BSPT) tested a sample at 12 dilutions with $99,000 \mathrm{mg}_{\text {soil }} / \mathrm{L}_{\text {diluent }}$ being the highest concentration for highly contaminated soil (Soil 1), and at 5 dilutions with $396,000 \mathrm{mg}_{\text {soil }} / \mathrm{L}_{\text {diluent }}$ being the highest concentration for lowcontaminated soil (Soil 2). Briefly $3.5 \mathrm{~g}$ sample were mixed with either $17.5 \mathrm{~mL}$ (Soil 1) or $4 \mathrm{~mL}$ (Soil 2) of diluent respectively, shaken for 10 minutes, centrifuged $3 \mathrm{~min}$ at $1000 \mathrm{~g}$ and analysed according to Microtox ${ }^{\circledR}$ BSPT assay. The bacterial reagent is sensitive to $\mathrm{pH}$, therefore samples with pH higher than 8.00 were adjusted using small aliquots of $\mathrm{HCl}(200 \mu \mathrm{L}$ at $0.25 \mathrm{M})$. A $100 \mathrm{~g} / \mathrm{L}$ zinc sulphate standard solution was used to check the performance of both operator and analytical system and the $95 \%$ confidence range was maintained below $15 \%$ variation throughout the study. The soil 
dilution that inhibits $50 \%\left(\mathrm{EC}_{50}\right)$ of the light output relative to was calculated for each sample, note that $\operatorname{Microtox}{ }^{\circledR} \mathrm{EC}_{50}$ values decline as toxicity increases.

\subsection{Data analysis}

Data analysis was performed on independent mesocosms duplicates for each amendment at the time points described $\left(0,30,90\right.$, and 180 days). Aromatic fractions were grouped as $\mathrm{EC}_{10}-\mathrm{EC}_{12}, \mathrm{EC}_{12}-\mathrm{EC}_{16}$, $\mathrm{EC}_{16}-\mathrm{EC}_{21}$, and $\mathrm{EC}_{21}-\mathrm{EC}_{35}$, aliphatic fractions were grouped as $\mathrm{EC}_{10}-\mathrm{EC}_{12}, \mathrm{EC}_{12}-\mathrm{EC}_{16}, \mathrm{EC}_{16}-\mathrm{EC}_{35}$, and $\mathrm{EC}_{35}-\mathrm{C}_{40}$ according to Coulon et al., (2010). The overall aromatic ( $\Sigma$ Aromatics), overall aliphatic ( $\Sigma$ Aliphatics) and total petroleum hydrocarbon $(\Sigma \mathrm{TPH})$ contents were also calculated (Table 1).

Repeated-measures ANOVA test was used to investigate the significance and relationship between soil amendment (biochar, compost, or un-amended) and incubation time on the toxicological response in model organisms (for uni-variate datasets, e.g bacteria count, soil respiration, Microtox ${ }^{\circledR}$ ). Permutational Multivariate Analysis of Variance (PERMANOVA) was used was used for multivariate datasets, to investigate the significance and relationship between soil amendment (biochar, compost, or un-amended) and incubation time on: (1) the bioavailable and readily available fraction (organic contaminants) or the pore water and exchangeable fraction of inorganic contaminants (heavy

metals/metalloids), (2) toxicological response in model organisms for multi-variate datasets (e.g seeds germination, earthworm lethality, PLFA profiles). Both Repeated-measures ANOVA and PERMANOVA were performed in R Studio using the "aov" and "adonis" function of the vegan library respectively (Oksanen et al., 2011).

To establish correlation between the bioavailable fraction measured by chemical means and the toxicity response of the bioassays, univariate linear regression analysis was used by applying the “corrplot" package (Oksanen et al., 2011). Further to this, multivariate analyses were used to examine the combined relationships between bioavailable concentrations and each toxicity dataset. The Mantel test for dissimilarity matrices was used to evaluate the correlation between the overall bioavailable concentrations (multivariate dataset, e.g. whole bioavailable concentration of organic compounds) 
and the toxicological response in multiple bioassays. Mantel tests were performed on scaled matrix by using either Euclidean (all data) or Bray-Curtis distance (for community composition comparisons e.g. PLFAs (Legendre and Legendre, 2012)) calculated with the "vegdist" function. Significance levels of each relationship were determined from the $p$ value and recognised as significant where $p<$ 0.05. All tests were computed with R Studio (Version 1.1.423 - (C) 2009-2018 RStudio, Inc.).

\section{Results and discussion}

\subsection{Soil characteristics}

The soil physicochemical properties of the two samples used in this study are summarised in Table 1. Textural soil analysis showed that Soil 1 was a coarse sand soil type while Soil 2 was fine-sandyloam. The ammonium and nitrate were relatively low in Soil 1 and high in Soil 2. The phosphate concentration was similar in both soils, and C: N: P ratio was 254:5:1 and 78:3:1 for Soil 1 and Soil 2 respectively; where the ratio varied by orders of magnitude in particular in relation to TC content. Indeed $\mathrm{C}: \mathrm{N}$ unbalanced ratio and nutrients deficiencies are often found in petroleum-contaminated soils along with a high carbon-to-nitrogen ratio (Saum et al., 2018).

Available P was within the range 16 - $45 \mathrm{mg} / \mathrm{kg}$ established by soil quality UK framework (Griffiths et al., 2018) for both soil samples, as well as TN; which even though measured quite low, was in the range $0.14-0.70 \mathrm{mg} / \mathrm{kg}$ measured by Bhogal et al. (2015) across seven experimental sites in the UK. The $\mathrm{pH}$ content of Soil 1 was alkaline $(\mathrm{pH}>8)$, while for Soil $2 \mathrm{pH}$ ranged between 5.5 - 7.9 which is similar to a previous study evaluating physical properties of nine UK soils (Mcgeough et al., 2016), and within the average range of 5.50 - 6.49 of over 200000 UK arable and grassland soils as measured by the Soil Analysis Report of Professional Agricultural Analysis Group (PAAG, UK) (PAAG, 2016) and Goulding and Systems (2016).

These conditions suggest that Soil 1 in particular could benefit from biostimulation with addition of compost. According to US EPA (2002) the appropriate C:N:P ratio for an active microbial population 
able to successfully bio remediate a contaminated soil is 100:10:1. The compost exhibited the following physicochemical composition and characteristics: $1.0 \% \mathrm{TN}, 328 \mathrm{mg} / \mathrm{kg}$ available phosphorous, $300 \mathrm{mg}-\mathrm{N} / \mathrm{kg}$ nitrate, $\mathrm{pH}$ 6. The biochar nutrient content was $0.9 \% \mathrm{TN}, 74 \mathrm{mg} / \mathrm{kg}$ available phosphorous, and $\mathrm{pH} 10$.

The overall TPH content of Soil 1 was 5 times higher than Soil 2. The GC-MS fingerprint was typical of weathered TPH with a predominance of low to medium chain aliphatic compounds $\left(\mathrm{EC}_{16-35}\right)$ and low to medium molecular weight aromatic compounds $\left(\mathrm{EC}_{16-21}\right)$ (Table 1). Other relevant soil and amendment properties are shown in Table 1.

\subsection{Chemical mixture fractions behaviour and distribution changes overtime}

\subsubsection{Extractable total, bioavailable and readily available hydrocarbons concentrations}

After 180 incubation the TPH total content decrease on average by 46 and $30 \%$ in Soil $1+$ Compost and Soil $2+$ Compost. The decrease can be explained by biodegradation, as the readily available and bioavailable TPH contents significantly decreased overtime (Figure 1 and 2, and Supplementary information Figure 1 and 2). The most significant changes were observed for the aromatics $\mathrm{EC}_{16-21}$ and aliphatic $\mathrm{EC}_{16-35}$ fractions where their total concentration decreased by $60 \%$ and $48 \%$ in Soil 1

+ Compost, and by $28 \%$ and $70 \%$ in (Soil $2+$ Compost). The bioavailable concentrations of the aromatics $\mathrm{EC}_{16-21}$ and the aliphatic $\mathrm{EC}_{16-35}$ fractions decreased by $92 \%$ and $27 \%$, respectively in Soil $1+$ Compost, and by $59 \%$ and $62 \%$ in Soil $2+$ Compost. The degradation of the medium and long chain aliphatic compounds $\left(\mathrm{EC}_{16-35}\right)$ and medium molecular weight aromatic compounds $\left(\mathrm{EC}_{16-21}\right)$ could be attributed to the biological activity which is supported by an increase in the viable microbial abundance and higher respiration rate (see section 3.3).

In contrast, in soils amended with biochar, TPH total content decreased by $18 \%$ in both samples, along with a decrease in TPH bioavailable concentration of 24 and $28 \%$ in Soil 1 and Soil 2 respectively. Additionally, in biochar amended soils, the TPH concentration was found to be 15-10 
$\%$ lower compared to un-amended soil samples, confirming that biochar was able to effectively lock the organic contaminants. Comparable to previous studies, compost addition was overall more efficient in promoting biodegradation than biochar (Cai et al., 2010; Han et al., 2016; Zhang et al., 2010).

After amendment, the most prominent residual hydrocarbon fractions were the high molecular weight aromatic fractions $\left(\mathrm{EC}_{21-35}\right)$ for both soils. This recalcitrant behaviour is often observed for larger molecules in aged contaminated soils, where residual petroleum hydrocarbons compounds tend to bind tightly to the soil matrix, forming soil aggregates able to entrap and retain the compounds and therefore limiting their bioavailability (Huesemann et al., 2004).

\subsubsection{HM and metalloids pseudo-total content, solid phase distribution, and availability}

$\mathrm{HM}$ and metalloids were almost entirely found in the non-exchangeable fraction (Supplementary information Figure $3 \mathrm{~A}$ and $\mathrm{B}$ ), and no major changes in their distribution were observed with incubation time (time effect $\mathrm{p}>0.05$ ), suggesting that these HM are unlikely to become available with time (Supplementary information Figure 4). The most mobilised elements were $\mathrm{Cu}>\mathrm{As}>\mathrm{Cr}>\mathrm{Zn}$ $>\mathrm{Ni}>\mathrm{Pb}$ for Soil 1 and $\mathrm{Zn}>\mathrm{Ni}>\mathrm{Pb}>\mathrm{As}>\mathrm{Cr}>\mathrm{Cu}$ for Soil 2, suggesting a common anthropogenic source for these elements. $\mathrm{Cu}, \mathrm{As}, \mathrm{Cr}, \mathrm{Zn}, \mathrm{Ni}$ and $\mathrm{Pb}$ are often found at gaswork site, as a result of the manufacturing process (CL:AIRE, 2015). The principal waste types at gasworks sites responsible for HM/metalloids contaminations includes: residual spent oxides from gas purification, by-products of carbonisation (ash, clinker residues), furnace residues (coke, cokebreeze), and residuals from batteries, pipelines, and paint (CL:AIRE, 2015; Wong, 2012). Additionally the pseudo-total concentrations of these elements was relatively low (Table 1 and Supplementary information Table 1

and Table 2), where only $\mathrm{As}, \mathrm{Pb}$ and $\mathrm{Zn}$ (Soil 2) and $\mathrm{Zn}$ (Soil 1) were found to exceed guideline values $(\mathrm{As}=32 \mathrm{mg} / \mathrm{kg}, \mathrm{Pb}=450 \mathrm{mg} / \mathrm{kg}, \mathrm{Zn}=150-200 \mathrm{mg} / \mathrm{kg})($ UK CLEA Soil Guideline Values (2009), EC Directive 86/278/EEC (1986)). 


\subsection{Indices of hydrocarbon fractions biodegradation}

\subsubsection{Microbial counts and respiration rate}

Changes in microbial community, biomass, and $\mathrm{CO}_{2}$ production can be used as indices of degradation rates (Chi and Hieu, 2017). In this study the positive effect of compost amendment on the microbial community was observed for both soils, while the effect of biochar addition was limited (Figure 3). This finding supports the idea that besides supplying nutrients, compost can provide additional microorganisms able to enhance the biodegradation process (Gandolfi et al., 2010). In addition, the higher specific surface area, associated with compost amendment (Table 1), provided a greater surface for interaction, thus potentially increasing the number of microorganisms attached to it, which may also lead to a higher degree of degradation (Ge et al., 2015).

Such effect seems to be more pronounced where initial nutrients level was low, and soil microbial activity and communities were initially distressed by high contaminants concentrations, as in Soil 1. Both incubation time $(\mathrm{p}=0.0004)$ and amendment $(\mathrm{p}=0.0007)$ significantly influenced soil respiration rate in Soil 1, while only Soil $2+$ Compost was found to be highly significant $(p=0.00002)$ (Figure 3).

At the onset Soil 1 had no measurable $\mathrm{CO}_{2}$ production (below detection limits) for all samples. Over the 90 days monitoring Soil $1+$ Compost increased by two orders of magnitude the numbers of culturable bacteria (data not shown) compared to Soil 1 un-amended, this translated into enhanced $\mathrm{CO}_{2}$ production with a steady increase in net mineralized $\mathrm{CO}_{2}$ (Figure 3 ). The positive effect of compost addition on the total number of culturable microorganisms has been previously observed in soil contaminated with diesel oil (Gandolfi et al., 2010) and heavy crude oil (Trejo-Hernández et al., 2007). Similar findings showed that bioavailable and readily available concentrations may be reduced when applying compost amendment without hindering biodegradation (Bielská et al., 2017; Marchal et al., 2013). The beneficial effect observed for compost- amended soil can be attributed to (1) the increase in nutrients content, (2) the enrichment of the microbial community, (3) a positive effect of 
$\mathrm{pH}$ adjustment (slightly alkaline $\mathrm{pH}$ of compost) towards a more neutral $\mathrm{pH}$ value (Kästner and Miltner, 2016).

Soil 2 demonstrated a slight decrease in net mineralized $\mathrm{CO}_{2}$ rate during the first 30 days, followed by an increase over the next 60 days (Figure 3); however compost and biochar amendments did not significantly affect the numbers of culturable bacteria (data not shown). Soil $2+$ Biochar showed a lower $\mathrm{CO}_{2}$ production, compared to Soil 2 + Compost, and a similar trend to un-amended soil, suggesting that the addition of biochar did not produce a significant advantage for the microbial community, in the sample with lower TPH contamination.

While many studies demonstrated the ability of biochar amendment to increase the population of microorganisms (Douds et al., 2014; Hua et al., 2011; Yoshizawa et al., 2005; Zhang and Sun, 2014), no significant increase of the number of culturable bacteria was observed in this study. In particular, all the above mentioned studies involve the use of a primary source of nutrients (green waste or sludge) along with biochar addition. Thus biochar used in combination with traditional composting can increase the quality of treatment (increasing particle-size distribution, creating free air space, improving cation exchange capacity); however, when applied on its own, it does not bring any benefit for the bacterial and fungal community. Moreover, the ineffectiveness of biochar in regards of reducing toxicity for microorganisms can have multiple explanations including: (1) biochar, may still contains PAH due to the pyrolysis (Hale et al., 2012) causing toxicity for the microorganisms (Oleszczuk et al., 2012; Quilliam et al., 2013); (2) biochar strong sorption capacity (Joseph et al., 2010) may reduce nutrients availability (Oleszczuk et al., 2013); (3) the lack of nutrients in the soil sample, was addressed in compost- amended mesocosms but not in biochar-amended ones.

\subsubsection{Phospholipid-derived fatty acids analysis}

As previously highlighted, compost amendment consistently generated an increase in viable microbial community and $\mathrm{CO}_{2}$ production for both soils; this finding was also supported by a significant shift in the microbial community composition over time, thus clearly differentiating 
compost amendment from un-amended soils (Figure 4). For Soil 1 and Soil $1+$ Biochar, a threefold increase of Gram negative and a net decrease of fungi (over $70 \%$ ) were observed between T0 (onset) and T180. Previous studies correlated petroleum hydrocarbons loss and PLFA specific for the total bacterial community of Gram-negative bacteria, and soil fungi (Al-Hawash et al., 2018; Bell et al., 2013; Margesin et al., 2007).

For the least contaminated soil, the microbial community composition for Soil 2 and Soil $2+$ Biochar was more subjected to changes during incubation, compared to Soil $2+$ Compost. We hypothesised that, in this soil sample, the biodiversity of indigenous microorganisms (provided by compost amendment) may have acted as a barrier to exogenous microorganisms (Kennedy et al., 2002) reducing population shifts. Both incubation time $(\mathrm{p}=0.001)$ and amendment applied $(\mathrm{p}=0.002)$ were found to be equally significantly affecting microbial community composition in both soil samples.

\subsection{Soil ecotoxicology}

\subsubsection{Seeds germination}

Both soil amended with compost had the highest percentage of seeds germination $(>90 \%)$, indicating that the toxic effect was lower compared to un-amended and biochar amended samples (Supplementary information Figure 5). For Soil 1 both incubation time and soil amendment applied were found to significantly affect germination rate $(p=0.001)$. Although a significant increase $(>40 \%)$ in seed germination was still recorded for Soil 1 and Soil $1+$ Biochar in peas (after 30 days Supplementary information Figure 5C) mustard and rye grass (after 90 days Supplementary information Figure 5A and Figure 5B), the rate and degree of growth were slower compared to uncontaminated soil (control), suggesting some time lag ecotoxicological effect.

In Soil 2 and Soil $2+$ Biochar the germination rate decreased at day 30, but remained constant for Soil $2+$ Compost. This can be explained by the fact that Soil 2 amended with compost relied on an established and a more stable microbial community (as previously highlighted in PLFA composition), 
which was able to degrade organic contaminations, along with a significant reduction in bioavailability, thus reducing toxicity. On the contrary Soil 2 and Soil $2+$ Biochar had a more dynamic microbial population along with a less effective microbial degradation (decrease in net mineralized $\mathrm{CO}_{2}$ ); therefore changes in contaminant concentration were likely to be mainly depending on sorption/desorption processes rather than microbial degradation. Indeed, changes in sorption-desorption equilibrium can drive the release of organic contaminants which were previously encapsulated in soil aggregates (Jiang et al., 2016), hence increasing compounds bioavailability and toxicity. This was observed for Soil 2 where bioavailable concentrations of $\mathrm{EC}_{21-35}$ and $\mathrm{EC}_{21-35}$ were higher at 30 days compared to the onset of the experiment (Figure 2) along with a lower germination rate recorded for mustard, rye grass, and pea seeds at 30 days (Supplementary information Figure 5 A, B, and C).

\subsubsection{Earthworms lethality}

Earthworm acute toxicity assay was more sensitive compared to seed germination, as both dermal absorption and feeding can impact E. fetida (Korte, 2003; Vijver et al., 2003). Condition index (Cl) for Soil 1 and Soil $1+$ Biochar remained 0 (mortality) at all sampling point, along with a significant decrease in weight (on average up to $50 \%$ reduction) (Table 2). In Soil $1+$ Compost, the $\mathrm{Cl}$ consistently increased across the sampling time. E. fetida was also less affected by changes in weight loss. Similar to the other bioassays, Soil 2 was seen as having a lower impact on $E$. fetida (Table 2). Neither amendment applied nor mesocosms incubation time were significantly affecting condition index in Soil $2(p>0.05)$. This can be explained by the fact that Soil 2 was overall less contaminated, and perhaps this specific ecotoxicological test may not be adequate (low sensitivity) to highlight the relationship between the two variables (toxicity/contamination). In this case the use of a chronic test, such as inhibition of earthworm reproduction,(OECD, 2004)) could have provided a more ecologically relevant endpoint rather than acute toxicity (Lionetto et al., 2012). 


\subsubsection{Microtox ${ }^{\circledR}$ Basic Solid Phase Test}

The use of Microtox ${ }^{\circledR}$ bioassay, in combination with the other ecotoxicological tests, provide a supplementary tool for a real-time assessment of toxicity associated not only with the presence of contaminants in a mixtures, but also with their potential mutual interactions (Kuczyńska et al., 2005). Previous findings highlight the positive effect of bioremediation in reducing toxicity of organic contaminants to $V$. fischeri (Khan et al., 2013, 2012; Macken et al., 2008).

At the onset of the experiment, the toxicity levels were similar for all samples due to the co-presence of organic and inorganic pollutants, however after 180 days the overall acute toxicity significantly decreased (EC50 increase), in particular for Soil $1+$ Compost (Figure 5). In comparison for Soil 2 changes in toxicity to $V$. fischeri were limited, as this sample was overall less contaminated. In particular in Soil + Biochar toxicity was halved due to a combination of bonding between contaminants and organic sorbent (biochar), and a reduction of the compounds bioavailability. This can provide an explanation for the difference observed in toxicity among the samples studied in spite of similar levels of TPH. Amendment alone $(p=0.00004)$, incubation time $(p=0.004)$ and combined effect of time and amendment $(\mathrm{p}=0.003)$ were found to be significantly affecting changes in $\mathrm{EC}_{50}$ for Soil 1 and Soil 2.

\subsection{Correlation between bioavailable fraction and bioassays}

The bioavailable (HP- $\beta$-CD extracted) and readily-available (methanol extracted) concentrations of the main hydrocarbon groups and HM/metalloids fractions were plotted along with the toxicological responses of the multiple bioassays (Figure 6). The strength of the correlations between the bioavailability-proxy and the toxicity data can provide an indication of which technique is more suitable for predicting site-specific bioavailability of complex chemical mixtures. Strong negative correlations were observed between bioavailable/readily available aromatic and aliphatic concentrations and the ecotoxicological assays (e.g bacteria count, soil respiration, seeds germination, and condition index) in particular in Soil $1+$ Compost and Soil 2+ Compost (Figure 6 c-f and d-e). 
Results indicate that when bioavailable/readily available concentrations decrease, the toxicity also decrease, thus diversity of microbial community increase along with soil respiration, condition index, and $\mathrm{EC}_{50}$ (Figure 6).

Even though, for both soils, un-amended and biochar amended samples often displayed a similar pattern in their biological responses for microbial count, soil respiration, PLFA profile, seeds germination and earthworm lethality, the correlation between bioavailability and ecotoxicology was different (Figure $6 \mathrm{a} \& \mathrm{~b}$ ). Less correlation was observed in Soil $1+$ Biochar highlighting that toxicity changes can be driven by multiple factors (combined effects) which may not be accounted for in univariate linear regression analysis (correlation).

Interestingly, for both Soil 1 and Soil 2, the HM/metalloids pore water concentrations were often found to be positively correlated (dark blue); meaning that when bioavailable concentrations is high, toxicity is low for the microbial bioassays (bacteria count, respiration and in some cases PLFA). Indeed moderate concentrations of HM have previously been reported to have a beneficial effect to microbial growth (Chen et al., 2015).

Multivariate analyses (Table 3) highlighted a statistical significant relationship $(p=0.008, p=0.007)$ between bioavailable concentrations of complex mixtures of TPH and seed germination assay, microbial growth (CFU), in Soil 1+ Compost and Soil $1+$ Biochar. No significant relationships identified through the Mantel test were observed for the low contaminated soil (Soil 2) where the overall, readily available and bioavailable TPH concentrations were not strongly correlated $\left(\mathrm{r}^{2}<0.75\right.$ and $p>0.05$ ) with the bioassays. As previously highlighted the effect of HM, in particular the dissolved elements present in the pore water fraction, was significant for the bacterial count in Soil 1 + Compost $(\mathrm{p}=0.028)$ and Soil $2+\operatorname{Biochar}(\mathrm{p}=0.049)$.

In this study we observed that toxicity can be highly variable in relation to the type of assay applied, suggesting that toxic effect can be driven by multiple different sources. This is consistent with the fact that various organisms, used for the ecotoxicological assays, are characterised by various levels 
of sensitivity to complex chemical mixtures (Isidori et al., 2003). Other studies also highlighted the challenge of establishing direct linear relationship between organics content and ecotoxicity parameters (Oleszczuk et al., 2014). For example Buss and Mašek (2014) show the significant effect of volatile organic compounds rather than bioavailable PAH concentrations on seed germination assay. However, the significant linear uni- and multivariate relationships $(\mathrm{p}<0.05)$ observed between the bioavailability-proxy and the toxicity data provides the necessary evidence that this integrated approach is suitable for predicting site-specific bioavailability of complex chemical mixtures and could potentially be implemented with confidence in a stepwise tiered approach.

\section{Conclusion}

In this study the effect of compost and biochar addition on two soils contaminated with complex chemical mixtures was evaluated with a particular attention to their influence on the chemical behaviour, bioavailability, and degradation of the chemical mixtures. In parallel the effect of bioavailability of complex chemical mixtures on the microbial community composition and soil ecotoxicology were assessed. The addition of compost was effective in enhancing TPH degradation with a reduction of $\geq 30 \%$ and reducing significantly soil toxicity (e.g. $\mathrm{EC}_{50}$ increased 60 and 7 times in Soil 1 and Soil 2, respectively). While biochar amendment was less effective in reducing total TPH ( $\leq 19 \%$ decrease), the TPH concentration was still 15-10\% lower compared to un-amended samples suggesting that biochar was able to effectively lock organic contaminants in soil. This was evidenced by a significant decrease in bioavailability of the aromatic $\mathrm{EC}_{16-21}$ and aliphatic $\mathrm{EC}_{16-35}$ compounds in both amended soils ( $\geq 80 \%$ ); yet the high molecular weight (HMW) aromatic compounds were not posing any risk, as none of the fractions were found to be significantly bioavailable in any of the soil samples tested. Heavy metals and metalloids were almost entirely found in the non-exchangeable fraction, and no major changes in their distribution were observed with incubation time, suggesting that there HM are unlikely to become available with time, thus not posing risk. In our study, the soil $\mathrm{pH}$ for both samples was found to be neutral or alkaline; this condition is responsible for reducing 
HM and metalloids mobility due to adsorption, desorption, and co-precipitation processes. This study shows that the concentration of low to medium chain aliphatic compounds and low to medium molecular weight aromatic compounds can be effectively reduced through degradation by compost amendment and to a lower extend stabilised by biochar amendment. Thus, these fractions should be considered and monitored when defining remediation end-points, as they are easily degraded by microorganisms and potentially constitute the drivers for toxicity reduction. Since a valid ecotoxicological assessment should reflect the changes of contaminant concentrations, toxicity, and bioavailability of the complex mixtures; in this study we attempted to combine the complexity of the biological indicators with the chemical analysis. The bioassays were selected based on ease of execution and environmental relevance, and were used to provide information on remediation effectiveness. Overall, this study highlighted that there was a significant relationship $(\mathrm{p}<0.05)$ between the bioavailable/readily available fraction of the chemical mixtures and the ecotoxicological bioassays. E. fetida CI at 14 daysearthworm survival, and the seed germination showed assay were that thecombining a range of bioassays best atprovide a meaning way to discriminating between the amended and un-amended soils(in particular for Soil 1). These assay are expected to be more reliable to be used in the risk assessment, and could significantly help to identify optimal remediation strategies, and contribute to change the over-conservative nature of the current risk assessments.

\section{Acknowledgements}

This work was completed as part of the REMEDIATE (Improved decision-making in contaminated land site investigation and risk assessment) H2020 Marie Skłodowska-Curie Actions (Grant agreement n. 643087). The authors also thank Dr Mark Cave (British Geological Survey) for his support with the chemometric identification of substrates and element distributions, and the Ecologia Environmental Solutions Limited and Paddock Geo Engineering for providing the soil samples necessary for this study. 


\section{Reference}

Adams, G.O., Fufeyin, P.T., Okoro, S.E., Ehinomen, I., Biology, E., 2015. Bioremediation, Biostimulation and Bioaugmention : A Review 3, 28-39.

Ahmad, M., Rajapaksha, A.U., Lim, J.E., Zhang, M., Bolan, N., Mohan, D., Vithanage, M., Lee, S.S., Ok, Y.S., 2014. Biochar as a sorbent for contaminant management in soil and water: A review. Chemosphere 99, 19-23.

Al-Hawash, A.B., Alkooranee, J.T., Abbood, H.A., Zhang, J., Sun, J., Zhang, X., Ma, F., 2018. Isolation and characterization of two crude oil-degrading fungi strains from Rumaila oil field, Iraq. Biotechnol. Reports 17, 104-109.

Baldantoni, D., Morelli, R., Bellino, A., Prati, M.V., Alfani, A., De Nicola, F., 2017. Anthracene and benzo(a)pyrene degradation in soil is favoured by compost amendment: Perspectives for a bioremediation approach. J. Hazard. Mater. 339, 395-400.

Bell, T.H., Yergeau, E., Juck, D.F., Whyte, L.G., Greer, C.W., 2013. Alteration of microbial community structure affects diesel biodegradation in an Arctic soil. FEMS Microbiol. Ecol. 85, $51-61$.

Bhogal et al., 2015. DC-Agri ; field experiments for quality digestate and compost in agriculture, WP1 report.

Bielská, L., Kah, M., Sigmund, G., Hofmann, T., Höss, S., 2017. Bioavailability and toxicity of pyrene in soils upon biochar and compost addition. Sci. Total Environ. 595, 132-140.

British Standards Institution, 2017. Soil quality : procedure for site-specific ecological risk assessment of soil contamination (soil quality TRIAD approach). British Standards Institution.

BS EN 13039, 2000. Soil improvers and growing media. Determination of organic matter content and ash.

BS EN 13654-2, 2001. Soil improvers and growing media. Determination of nitrogen. Dumas 
method.

Buss, W., Mašek, O., 2014. Mobile organic compounds in biochar - A potential source of contamination - Phytotoxic effects on cress seed (Lepidium sativum) germination. J. Environ. Manage. 137, 111-119.

Cachada, A., Ferreira da Silva, E., Duarte, A.C., Pereira, R., 2016. Risk assessment of urban soils contamination: The particular case of polycyclic aromatic hydrocarbons. Sci. Total Environ. $551-552,271-284$.

Cai, Z., Zhou, Q., Peng, S., Li, K., 2010. Promoted biodegradation and microbiological effects of petroleum hydrocarbons by Impatiens balsamina L. with strong endurance. J. Hazard. Mater. $183,731-737$.

Cave, M.R., Milodowski, A.E., Friel, E.N., 2004. Evaluation of a method for identification of host physico-chemical phases for trace metals and measurement of their solid-phase partitioning in soil samples by nitric acid extraction and chemometric mixture resolution. Geochemistry Explor. Environ. Anal. 4, 71-86.

Chen, M., Xu, P., Zeng, G., Yang, C., Huang, D., Zhang, J., 2015. Bioremediation of soils contaminated with polycyclic aromatic hydrocarbons, petroleum, pesticides, chlorophenols and heavy metals by composting: Applications, microbes and future research needs. Biotechnol. Adv. 33, 745-755.

Chi, T.T., Hieu, D.T., 2017. Using the respiratory quotient as a microbial indicator to monitor soil biodegradation $55,51-56$.

Cipullo, S., Snapir, B., Tardif, S., Campo, P., Prpich, G., Coulon, F., 2018. Insights into mixed contaminants interactions and its implication for heavy metals and metalloids mobility, bioavailability and risk assessment. Sci. Total Environ. 645, 662-673.

CL:AIRE, 2015. Soil and Groundwater Remediation Technologies for Former Gasworks and 
Gasholder Sites.

Coulon, F., Whelan, M.J., Paton, G.I., Semple, K.T., Villa, R., Pollard, S.J.T., 2010. Multimedia fate of petroleum hydrocarbons in the soil: Oil matrix of constructed biopiles. Chemosphere $81,1454-1462$.

Cox, S.F., Chelliah, M.C.M., McKinley, J.M., Palmer, S., Ofterdinger, U., Young, M.E., Cave, M.R., Wragg, J., 2013. The importance of solid-phase distribution on the oral bioaccessibility of $\mathrm{Ni}$ and $\mathrm{Cr}$ in soils overlying Palaeogene basalt lavas, Northern Ireland. Environ. Geochem. Health 35, 553-567.

Davie-Martin, C.L., Stratton, K.G., Teeguarden, J.G., Waters, K.M., Simonich, S.L.M., 2017. Implications of Bioremediation of Polycyclic Aromatic Hydrocarbon-Contaminated Soils for Human Health and Cancer Risk. Environ. Sci. Technol. 51: 9458-9468.

Dawson, J.J.C., Godsiffe, E.J., Thompson, I.P., Ralebitso-Senior, T.K., Killham, K.S., Paton, G.I., 2007. Application of biological indicators to assess recovery of hydrocarbon impacted soils. Soil Biol. Biochem. 39, 164-177.

Denys, S., Caboche, J., Tack, K., Rychen, G., Wragg, J., Cave, M., Jondreville, C., Feidt, C., 2012. In Vivo Validation of the Unified BARGE Method to Assess the Bioaccessibility of Arsenic, Antimony, Cadmium, and Lead in Soils. Environ. Sci. Technol. 46, 6252-6260.

Douds, D.D., Lee, J., Uknalis, J., Boateng, A.A., Ziegler-Ulsh, C., 2014. Pelletized biochar as a carrier for AM fungi in the on-farm system of inoculum production in compost and vermiculite mixtures. Compost Sci. Util. 22, 253-262.

Egene, C.E., Van Poucke, R., Ok, Y.S., Meers, E., Tack, F.M.G., 2018. Impact of organic amendments (biochar, compost and peat) on $\mathrm{Cd}$ and $\mathrm{Zn}$ mobility and solubility in contaminated soil of the Campine region after three years. Sci. Total Environ. 626, 195-202.

European Commission, 1986. Protection of the Environment, and in particular of the soil, when 
sewage sludge is used in agriculture. Off. J. Eur. Communities 4, 6-12.

Frostegård, Å., Tunlid, A., Bååth, E., Frostegård, A., Tunlid, A., Bååth, E., 1993. Phospholipid Fatty Acid composition, biomass, and activity of microbial communities from two soil types experimentally exposed to different heavy metals. Appl. Environ. Microbiol. 59, 3605-17.

Gandolfi, I., Sicolo, M., Franzetti, A., Fontanarosa, E., Santagostino, A., Bestetti, G., 2010. Influence of compost amendment on microbial community and ecotoxicity of hydrocarboncontaminated soils. Bioresour. Technol. 101, 568-575.

Ge, J., Huang, G., Huang, J., Zeng, J., Han, L., 2015. Mechanism and kinetics of organic matter degradation based on particle structure variation during pig manure aerobic composting. J. Hazard. Mater. 292, 19-26.

Giller, K.E., Witter, E., McGrath, S.P., 2009. Heavy metals and soil microbes. Soil Biol. Biochem. 41, 2031-2037.

Goulding, K.W.T., Systems, G., 2016. Soil acidification and the importance of liming agricultural soils with particular reference to the United Kingdom. Soil Use Manag. 32, 390-399.

Griffiths, B., Hargreaves, P., Bhogal, A., Stockdale, E., 2018. Final Report No . 91140002-02 Soil Biology and Soil Health Partnership Project 2 : Selecting methods to measure soil health and soil biology and the development of a soil health scorecard.

Hale, S.E., Lehmann, J., Rutherford, D., Zimmerman, A.R., Bachmann, R.T., Shitumbanuma, V., O’Toole, A., Sundqvist, K.L., Arp, H.P.H., Cornelissen, G., 2012. Quantifying the Total and Bioavailable Polycyclic Aromatic Hydrocarbons and Dioxins in Biochars. Environ. Sci. Technol. 46, 2830-2838.

Han, T., Zhao, Z., Bartlam, M., Wang, Y., 2016. Combination of biochar amendment and phytoremediation for hydrocarbon removal in petroleum-contaminated soil. Environ. Sci. Pollut. Res. 23, 21219-21228. 
Hodson, M.E., Vijver, M.G., Peijnenburg, W.J.G.M., 2011. Bioavalibility in Soils BT - Dealing with Contaminated Sites: From Theory towards Practical Application. In: Swartjes, F.A. (Ed.), . Springer Netherlands, Dordrecht, pp. 721-746.

Hou, D., Al-tabbaa, A., 2014. Sustainability: A new imperative in contaminated land remediation. Environ. Sci. Policy 39, 25-34.

Hua, L., Chen, Y., Wu, W., Ma, H., 2011. Microorganism communities and chemical characteristics in sludge- bamboo charcoal composting system. Environ. Technol. 32, 663-672.

Huesemann, M.H., Hausmann, T.S., Fortman, T.J., 2004. Does bioavailability limit biodegradation? A comparison of hydrocarbon biodegradation and desorption rates in aged soils. Biodegradation 15, 261-274.

Isidori, M., Lavorgna, M., Nardelli, A., Parrella, A., 2003. Toxicity identification evaluation of leachates from municipal solid waste landfills : a multispecies approach 52, 85-94.

ISO 10390, 2005. Soil quality -- Determination of $\mathrm{pH}$.

ISO 11047, 1998. Soil quality - Determination of cadmium, chromium, cobalt, copper, lead, manganese, nickel and zinc - Flame and electrothermal atomic absorption spectrometric methods.

ISO 11263, 1994. Soil quality -Determination of phosphorus - Spectrometric determination of phosphorus soluble in sodium hydrogen carbonate solution.

ISO 11277, 2009. Soil quality -Determination of particle size distribution in mineral soil material Method by sieving and sedimentation.

ISO 11465, 1993. Soil quality - Determination of dry matter and water content on a mass basis Gravimetric method.

Jackson E., Farrington D. S., Henderson K. 1986. The analysis of agricultural materials: a manual 
of the analytical methods used by the Agricultural Development and Advisory Service. No.427 (third edition),Ministry of Agriculture, Fisheries and Food, $248 \mathrm{pp}$.

Jiang, Y., Brassington, K.J., Prpich, G., Paton, G.I., Semple, K.T., Pollard, S.J.T., Coulon, F., 2016. Insights into the biodegradation of weathered hydrocarbons in contaminated soils by bioaugmentation and nutrient stimulation. Chemosphere 161, 300-307.

Joseph, S.D., Camps-Arbestain, M., Lin, Y., Munroe, P., Chia, C.H., Hook, J., van Zwieten, L., Kimber, S., Cowie, A., Singh, B.P., Lehmann, J., Foidl, N., Smernik, R.J., Amonette, J.E., 2010. An investigation into the reactions of biochar in soil. Soil Res. 48, 501-515.

Karbassi, A.R., Shankar, R., 2005. Geochemistry of two sediment cores from the west coast of India. Int. J. Environ. Sci. Technol. 1, 307-316.

Kästner, M., Miltner, A., 2016. Application of compost for effective bioremediation of organic contaminants and pollutants in soil. Appl. Microbiol. Biotechnol. 100, 3433-3449.

Kennedy, T.A., Naeem, S., Howe, K.M., Knops, J.M.H., Tilman, D., Reich, P., 2002. Biodiversity as a barrier to ecological invasion. Nature 417, 636-638.

Khan, M.I., Cheema, S.A., Tang, X., Hashmi, M.Z., Shen, C., Park, J., Chen, Y., 2013. A battery of bioassays for the evaluation of phenanthrene biotoxicity in soil. Arch. Environ. Contam. Toxicol. 65, 47-55.

Khan, M.I., Cheema, S.A., Tang, X., Shen, C., Sahi, S.T., Jabbar, A., Park, J., Chen, Y., 2012. Biotoxicity assessment of pyrene in soil using a battery of biological assays. Arch. Environ. Contam. Toxicol. 63, 503-512.

Kienzler, A., Bopp, S.K., van der Linden, S., Berggren, E., Worth, A., 2016. Regulatory assessment of chemical mixtures: Requirements, current approaches and future perspectives. Regul. Toxicol. Pharmacol. 80, 321-334.

Kim, M.S., Min, H.G., Koo, N., Park, J., Lee, S.H., Bak, G.I., Kim, J.G., 2014. The effectiveness of 
spent coffee grounds and its biochar on the amelioration of heavy metals-contaminated water and soil using chemical and biological assessments. J. Environ. Manage. 146, 124-130.

Kim, R.-Y.Y., Yoon, J.-K.K., Kim, T.-S.S., Yang, J.E., Owens, G., Kim, K.-R.R., 2015.

Bioavailability of heavy metals in soils: definitions and practical implementation — a critical review. Environ. Geochem. Health 37, 1041-1061.

Korte, G.D.E., 2003. Elucidating the Routes of Exposure for Organic Chemicals in the Earthworm , Eisenia andrei ( Oligochaeta ) 37, 3399-3404.

Kuczyńska, A., Wolska, L., Namieśnik, J., 2005. Application of Biotests in Environmental Research. Crit. Rev. Anal. Chem. 35, 135-154.

Kuppusamy, S., Venkateswarlu, K., Megharaj, M., Mayilswami, S., Lee, Y.B., 2017. Risk-based remediation of polluted sites: A critical perspective. Chemosphere 186, 607-615.

Langdon, C.J., Piearce, T.G., Black, S., Semple, K.T., 1999. Resistance to arsenic-toxicity in a population of the earthworm Lumbricus rubellus. Soil Biol. Biochem. 31, 1963-1967.

Legendre, P., Legendre, L.F.J., 2012. Numerical Ecology, Developments in Environmental Modelling. Elsevier.

Lionetto, M.G., Calisi, A., Schettino, T., 2012. Earthworm biomarkers as tools for soil pollution assessment. Soil Heal. L. Use Manag. 305-332.

Liu, W.J., Jiang, H., Yu, H.Q., 2015. Development of Biochar-Based Functional Materials: Toward a Sustainable Platform Carbon Material. Chem. Rev. 115, 12251-12285.

López, R., Hurtado, M.D., Cabrera, F., 2002. Compost properties related to particle size. Waste Manag. Environ. 56, 1-788.

Macken, A., Giltrap, M., Foley, B., McGovern, E., McHugh, B., Davoren, M., 2008. A model compound study: The ecotoxicological evaluation of five organic contaminants employing a 
battery of marine bioassays. Environ. Pollut. 153, 627-637.

Marchal, G., Smith, K.E.C., Rein, A., Winding, A., Trapp, S., Karlson, U.G., 2013. Comparing the desorption and biodegradation of low concentrations of phenanthrene sorbed to activated carbon, biochar and compost. Chemosphere 90, 1767-1778.

Margesin, R., Hämmerle, M., Tscherko, D., 2007. Microbial activity and community composition during bioremediation of diesel-oil-contaminated soil: Effects of hydrocarbon concentration, fertilizers, and incubation time. Microb. Ecol. 53, 259-269.

Mazzeo, D.E.C.., Ventura-Camargo, B.C.., L.R.D., S., M.A., M.-M., 2014. Endpoints and bioassays to asses bioremediation efficiency of contaminated soils, Bioremediation: Processes, Challenges and Future Prospects.

Mcgeough, K.L., Watson, C.J., Müller, C., Laughlin, R.J., Chadwick, D.R., 2016. Evidence that the ef fi cacy of the nitrification inhibitor dicyandiamide ( DCD ) is affected by soil properties in UK soils 94, 222-232.

National Research Council, Council, N.R., 2003. Bioavailability of Contaminants in Soils and Sediments: Processes, Tools, and Applications. The National Academies Press, Washington, DC.

Natural England Technical Information Note TIN037, 2008. Soil texture 1-6.

Novak, J.M., Ippolito, J.A., Ducey, T.F., Watts, D.W., Spokas, K.A., Trippe, K.M., Sigua, G.C., Johnson, M.G., 2018. Remediation of an acidic mine spoil : Miscanthus biochar and lime amendment affects metal availability, plant growth, and soil enzyme activity. Chemosphere 205, 709-718.

OECD, 2004. OECD Guidelines for the Testing of Chemicals; Section 2: Effects on Biotic Systems (Test No. 222: Earthworm Reproduction Test, Eisenia fetida/Eisenia andrei).

Ogundiran, M.B., Osibanjo, O., 2009. Mobility and speciation of heavy metals in soils impacted by 
hazardous waste. Chem. Speciat. Bioavailab. 21, 59-69.

Oksanen, A.J., Blanchet, F.G., Kindt, R., Legen-, P., Minchin, P.R., Hara, R.B.O., Simpson, G.L., Soly-, P., Stevens, M.H.H., Wagner, H., 2011. Package ' vegan .'

Oleszczuk, P., Hale, S.E., Lehmann, J., Cornelissen, G., 2012. Activated carbon and biochar amendments decrease pore-water concentrations of polycyclic aromatic hydrocarbons (PAHs) in sewage sludge. Bioresour. Technol. 111, 84-91.

Oleszczuk, P., Jo, I., Ku, M., Futa, B., Pranagal, J., 2014. Microbiological , biochemical and ecotoxicological evaluation of soils in the area of biochar production in relation to polycyclic aromatic hydrocarbon content 213, 502-511.

Oleszczuk, P., Jośko, I., Kuśmierz, M., 2013. Biochar properties regarding to contaminants content and ecotoxicological assessment. J. Hazard. Mater. 260, 375-382.

Ortega-Calvo, J.-J.J., Harmsen, J., Parsons, J.R., Semple, K.T., Aitken, M.D., Ajao, C., Eadsforth, C., Galay-Burgos, M., Naidu, R., Oliver, R., Peijnenburg, W.J.G.M.G.M., Römbke, J., Streck, G., Versonnen, B., 2015. From Bioavailability Science to Regulation of Organic Chemicals. Environ. Sci. Technol. 49, 10255-10264.

PAAG, 2016. Collation of data from routine soil analysis in the UK 1-11.

Papadopoulos, A., Paton, G.I., Reid, J., Semple, K.T., 2007. Prediction of PAH biodegradation in field contaminated soils using a cyclodextrin extraction technique 516-522.

Park, J.H., Choppala, G.K., 2011. Biochar reduces the bioavailability and phytotoxicity of heavy metals 439-451.

Paton, G.I., Viventsova, E., Kumpene, J., Wilson, M.J., Weitz, H.J., Dawson, J.J.C., 2006. An ecotoxicity assessment of contaminated forest soils from the Kola Peninsula. Sci. Total Environ. 355, 106-117. 
Pawlett, M., Ritz, K., Dorey, R.A., Rocks, S., Ramsden, J., Harris, J.A., 2013. The impact of zerovalent iron nanoparticles upon soil microbial communities is context dependent. Environ. Sci. Pollut. Res. 20, 1041-1049.

Quideau, S.A., McIntosh, A.C.S., Norris, C.E., Lloret, E., Swallow, M.J.B., Hannam, K., 2016. Extraction and Analysis of Microbial Phospholipid Fatty Acids in Soils. J. Vis. Exp. 114, e54360:1-9.

Quilliam, R.S., Glanville, H.C., Wade, S.C., Jones, D.L., 2013. Life in the “charosphere” - Does biochar in agricultural soil provide a significant habitat for microorganisms? Soil Biol. Biochem. 65, 287-293.

Reid, B.J., Stokes, J.D., Jones, K.C., Semple, K.T., 2000. Nonexhaustive cyclodextrin-based extraction technique for the evaluation of PAH bioavailability. Environ. Sci. Technol. 34, 3174-3179.

Risdon, G.C., Pollard, S.J.T., Brassington, K.J., McEwan, J.N., Paton, G.I., Semple, K.T., Coulon, F., 2008. Development of an analytical procedure for weathered hydrocarbon contaminated soils within a UK risk-based framework. Anal. Chem. 80, 7090-7096.

Sarsby, R., Meggyes, T., 2009. Construction for a Sustainable Environment. CRC Press.

Saum, L., Jiménez, M.B., Crowley, D., 2018. Influence of biochar and compost on phytoremediation of oil-contaminated soil. Int. J. Phytoremediation 20, 54-60.

Semple, K.T., Morriss, a. W.J., Paton, G.I., 2003. Bioavailability of hydrophobic organic contaminants in soils: fundamental concepts and techniques for analysis. Eur. J. Soil Sci. 54, 809-818.

Singh, A., Ward, O.P., 2004. Applied Bioremediation and Phytoremediation, Soil Biology. Springer Berlin Heidelberg.

Speight, J.G., El-Gendy, N.S., 2017. Introduction to Petroleum Biotechnology. Elsevier Science. 
Sundaray, S.K., Nayak, B.B., Lin, S., Bhatta, D., 2011. Geochemical speciation and risk assessment of heavy metals in the river estuarine sediments - A case study: Mahanadi basin, India. J. Hazard. Mater. 186, 1837-1846.

Taccari, M., Milanovic, V., Comitini, F., Casucci, C., Ciani, M., 2012. International Biodeterioration \& Biodegradation Effects of biostimulation and bioaugmentation on diesel removal and bacterial community. Int. Biodeterior. Biodegradation 66, 39-46.

Trejo-Hernández, M.R., Ortiz, A., Okoh, A.I., Morales, D., Quintero, R., 2007. Biodegradation of heavy crude oil Maya using spent compost and sugar cane bagasse wastes. Chemosphere 68, $848-855$.

Tunlid, A., 1992. Biochemical analysis of biomass, community structure, nutritional status and metabolic activity of microbial communities in soil. Soil Biochem. 7, 229-262.

U.S. Environmental Protection Agency, 2007. The The Use of Soil Amendments for Remediation , Revitalization, and Reuse.

Udovic, M., Drobne, D., Lestan, D., 2013. An in vivo invertebrate bioassay of Pb, Zn and Cd stabilization in contaminated soil. Chemosphere 92, 1105-1110.

US EPA, 2002. Application, performance, and costs of biotreatment technologies for contaminated soils., Epa/600/R-03/037.

Van Poucke, R., Ainsworth, J., Maeseele, M., Ok, Y.S., Meers, E., Tack, F.M.G., 2018. Chemical stabilization of Cd-contaminated soil using biochar. Appl. Geochemistry 88, 122-130.

Vijver, M.G., Vink, J.P.M., Miermans, C.J.H., Gestel, C.A.M. Van, 2003. Oral sealing using glue : a new method to distinguish between intestinal and dermal uptake of metals in earthworms 35 , $125-132$.

Wang, T., Sun, H., Ren, X., Li, B., Mao, H., 2017. Evaluation of biochars from different stock materials as carriers of bacterial strain for remediation of heavy metal-contaminated soil. Sci. 
Rep. 1-10.

Wang, Y., Li, F., Rong, X., Song, H., Chen, J., 2017. Remediation of Petroleum-contaminated Soil Using Bulrush Straw Powder, Biochar and Nutrients. Bull. Environ. Contam. Toxicol. 98, 690-697.

Wong, M.H., 2012. Environmental Contamination: Health Risks and Ecological Restoration. Taylor \& Francis.

Wragg, J., Cave, M., Gregory, S., 2014. The Solid Phase Distribution and Bioaccessibility of Arsenic , Chromium, and Nickel in Natural Ironstone Soils in the UK. Applied and Environmental Soil Science 2014, Article ID 924891, 12 pages

Yoshizawa, S., Tanaka, S., Ohata, M., Mineki, S., Goto, S., Fujioka, K., Kokubun, T., 2005. Composting of food garbage and livestock waste containing biomass charcoal. Proc. Int. Conf. Nat. Resour. Environ. Manag. 8, 2011.

Zhang, L., Sun, X., 2014. Changes in physical, chemical, and microbiological properties during the two-stage co-composting of green waste with spent mushroom compost and biochar. Bioresour. Technol. 171, 274-284.

Zhang, Z., Zhou, Q., Peng, S., Cai, Z., 2010. Remediation of petroleum contaminated soils by joint action of Pharbitis nil L. and its microbial community. Sci. Total Environ. 408, 5600-5605. 
Tables - Linking bioavailability and toxicity changes of complex chemicals mixture to support decision making for remediation endpoint of contaminated soils - Cipullo et al.

Table 1: Physicochemical characteristics of the genuine contaminated soil samples collected in Kent (Soil 1) and Northamptonshire (Soil 2) UK, and the biochar (Carbon Gold UK) and compost (Westland Horticulture Ltd UK) treatment materials used in the mesocosms setup.

\begin{tabular}{|c|c|c|c|c|c|}
\hline Characteristics & Analysis & Soil 1 & Soil 2 & Biochar & Compost \\
\hline \multirow{9}{*}{ Elements } & Total N (\%) & 0.4 & 0.2 & 0.9 & 1 \\
\hline & Total C (\%) & 18.3 & 5.8 & 59 & 40.2 \\
\hline & Total P (\%) & 0.07 & 0.07 & n.a & n.a \\
\hline & $\mathrm{C}: \mathrm{N}: \mathrm{P}$ & 254:5:1 & 78:3:01 & n.a & n.a \\
\hline & $\mathrm{C}: \mathrm{N}$ & 49.6 & 23.7 & 64.7 & 42.3 \\
\hline & Total P (mg/kg) & 727.5 & 750.1 & n.a & n.a \\
\hline & Available P (mg/kg) & 35 & 33.7 & 74.1 & 328.1 \\
\hline & Ammonium (mg-N/kg) & 9.5 & 71 & 0 & 0 \\
\hline & Nitrate $(\mathrm{mg}-\mathrm{N} / \mathrm{kg})$ & 2 & 18 & 0 & 310 \\
\hline \multirow{2}{*}{ Physical properties } & Dry matter content $\mathrm{W}_{\mathrm{dm}}(\%)$ & 93.2 & 85.4 & 79.4 & 31.3 \\
\hline & Water content $(\%)$ & 7.3 & 17.2 & 25.9 & 219.3 \\
\hline \multirow{2}{*}{ Chemical properties } & $\mathrm{pH}$ & 9.8 & 7.4 & 10 & 6 \\
\hline & LOI $(\%)$ & 19.1 & 8.8 & 76 & 78.7 \\
\hline \multirow{8}{*}{ Particle size } & Organic fractions: & & & & \\
\hline & $\% 10-20 \mathrm{~mm}$ & n.a & n.a & 22.8 & 54.5 \\
\hline & $\% 2-10 \mathrm{~mm}$ & n.a & n.a & 22.2 & 24.7 \\
\hline & $\% 0.6-2 \mathrm{~mm}$ (Coarse) & n.a & n.a & 15.5 & 7.5 \\
\hline & $\% 0.2-0.6 \mathrm{~mm}$ (Medium) & n.a & n.a & 37.7 & 9.0 \\
\hline & $\% 0.06-0.2 \mathrm{~mm}$ (Fine) & n.a & n.a & 1.7 & 4.5 \\
\hline & Mineral fractions: & & & & \\
\hline & $\% 0.6-2 \mathrm{~mm}$ (Coarse sand) & 46 & 7.8 & n.a & n.a \\
\hline
\end{tabular}




\begin{tabular}{|c|c|c|c|c|c|}
\hline & $\% 0.2-0.6 \mathrm{~mm}$ (Medium sand) & 26.7 & 21.7 & n.a & n.a \\
\hline & $\% 0.06-0.2 \mathrm{~mm}$ (Fine sand) & 15.4 & 23.2 & n.a & n.a \\
\hline & $\% 0.002 \mathrm{~mm}-0.06 \mathrm{~mm}$ (Silt) & 11 & 32.8 & n.a & n.a \\
\hline & $\%<0.002 \mathrm{~mm}$ (Clay) & 1 & 14.6 & n.a & n.a \\
\hline & Soil type & Coarse Sand & Fine Sandy Loam & n.a & n.a \\
\hline \multirow{9}{*}{$\begin{array}{l}\text { Average* heavy metals and } \\
\text { metalloids content }(\mathrm{mg} / \mathrm{kg})\end{array}$} & As & $29.6 \pm 2.6$ & $47.8 \pm 5.9$ & n.a & n.a \\
\hline & $\mathrm{Cd}$ & $<\mathrm{d} .1$ & $<\mathrm{d} .1$ & n.a & n.a \\
\hline & $\mathrm{Cr}$ & $29.6 \pm 2.0$ & $48.2 \pm 1.7$ & n.a & n.a \\
\hline & $\mathrm{Cu}$ & $54.2 \pm 3.1$ & $17.8 \pm 2.2$ & n.a & n.a \\
\hline & $\mathrm{Hg}$ & $<\mathrm{d} .1$ & $<\mathrm{d} .1$ & n.a & n.a \\
\hline & $\mathrm{Ni}$ & $28.2 \pm 6.9$ & $20.7 \pm 5.3$ & n.a & n.a \\
\hline & $\mathrm{Pb}$ & $78.5 \pm 0.6$ & $188.8 \pm 26.1$ & n.a & n.a \\
\hline & $\mathrm{Se}$ & $4.1 \pm 0.2$ & $4.2 \pm 0.7$ & n.a & n.a \\
\hline & $\mathrm{Zn}$ & $243.9 \pm 37.8$ & $162.2 \pm 10.3$ & n.a & n.a \\
\hline \multirow{11}{*}{$\begin{array}{l}\text { Average* petroleum } \\
\text { hydrocarbons content }(\mathrm{mg} / \mathrm{kg})\end{array}$} & $\mathrm{EC}_{10-12}$ & $23.9 \pm 8.3$ & $15.2 \pm 1.2$ & n.a & n.a \\
\hline & $\mathrm{EC}_{12-16}$ & $86.1 \pm 3.0$ & $24.4 \pm 2.3$ & n.a & n.a \\
\hline & $\mathrm{EC}_{16-35}$ & $1002.0 \pm 18.3$ & $21.3 \pm 1.5$ & n.a & n.a \\
\hline & $\mathrm{EC}_{35-40}$ & $<\mathrm{d} .1$ & $<\mathrm{d} .1$ & n.a & n.a \\
\hline & $\Sigma$ Aliphatics & $1112.4 \pm 52.9$ & $95.9 \pm 6.3$ & n.a & n.a \\
\hline & $\mathrm{EC}_{10-12}$ & $<\mathrm{d} .1$ & $<\mathrm{d} .1$ & n.a & n.a \\
\hline & $\mathrm{EC}_{12-16}$ & $599 \pm 20.09$ & $717.2 \pm 4.7$ & n.a & n.a \\
\hline & $\mathrm{EC}_{16-21}$ & $4249.1 \pm 135.4$ & $1026.6 \pm 70.3$ & n.a & n.a \\
\hline & $\mathrm{EC}_{21-35}$ & $3201.9 \pm 69.8$ & $61.2 \pm 2.8$ & n.a & n.a \\
\hline & $\Sigma$ Aromatics & $8050.2 \pm 226.1$ & $1839.7 \pm 81.3$ & n.a & n.a \\
\hline & $\Sigma \mathrm{TPH}$ & $9162.7 \pm 278.9$ & $1900.9 \pm 78.5$ & n.a & n.a \\
\hline
\end{tabular}

$\mathrm{N}$ : nitrogen, $\mathrm{C}$ : carbon, P: phosphorous, $\mathrm{W}_{\mathrm{dm}}$ : dry matter, LOI: loss of ignition, $\mathrm{n}$.a: not available, d.l: detection limit

*Values for heavy metals/metalloids and petroleum hydrocarbons are provided based on average of duplicate measurement \pm standard deviation 
Table 2: Average Condition Index (CI) of E. Fetida and weight loss (percentages) in earthworm acute toxicity bioassay, at the four sampling times $(0,30,90$, and 180 days) for Soil 1 and Soil 2 treated with compost, biochar, or un-amended. Condition index ranged from 0-2 where 0= mortality.

\begin{tabular}{|c|c|c|c|c|c|c|c|c|c|c|c|c|c|}
\hline \multirow{7}{*}{$\begin{array}{c}\text { Soil } \\
1\end{array}$} & & \multicolumn{4}{|c|}{ Compost } & \multicolumn{4}{|c|}{ Biochar } & \multicolumn{4}{|c|}{ Un-amended } \\
\hline & \multirow[b]{2}{*}{ CI 3 days } & 0 & 30 & 90 & 180 & 0 & 30 & 90 & 180 & 0 & 30 & 90 & 180 \\
\hline & & 0.0 & 0.3 & 1.5 & 2.0 & 0.0 & 0.0 & 0.0 & 0.0 & 0.0 & 0.0 & 0.0 & 0.0 \\
\hline & CI 7 days & 0.0 & 0.0 & 1.0 & 2.0 & 0.0 & 0.0 & 0.0 & 0.0 & 0.0 & 0.0 & 0.0 & 0.0 \\
\hline & \multirow{3}{*}{$\begin{array}{l}\text { CI } 14 \text { days } \\
\% \text { weight } \\
\text { loss/gain } \\
\text { stdev }\end{array}$} & 0.0 & 0.0 & 1.0 & 2.0 & 0.0 & 0.0 & 0.0 & 0.0 & 0.0 & 0.0 & 0.0 & 0.0 \\
\hline & & -34.9 & -20.1 & -14.3 & 7.4 & -53.0 & -50.3 & -64.0 & -50.0 & -55.5 & -37.0 & -57.1 & -50.0 \\
\hline & & 2.0 & 40.5 & 54.5 & 4.2 & 6.2 & 1.8 & 23.4 & 0.0 & 1.1 & 0.4 & 4.0 & 0.0 \\
\hline \multirow{7}{*}{$\begin{array}{c}\text { Soil } \\
2\end{array}$} & & \multicolumn{4}{|c|}{ Compost } & \multicolumn{4}{|c|}{ Biochar } & \multicolumn{4}{|c|}{ Un-amended } \\
\hline & & 0 & 30 & 90 & 180 & 0 & 30 & 90 & 180 & 0 & 30 & 90 & 180 \\
\hline & CI 3 days & 1.4 & 2.0 & 2.0 & 1.8 & 2.0 & 2.0 & 2.0 & 2.0 & 2.0 & 2.0 & 2.0 & 2.0 \\
\hline & CI 7 days & 1.5 & 1.8 & 1.3 & 1.8 & 1.3 & 1.8 & 2.0 & 2.0 & 2.0 & 2.0 & 2.0 & 2.0 \\
\hline & CI 14 days & 1.4 & 1.8 & 1.5 & 1.7 & 1.9 & 1.8 & 1.7 & 1.7 & 1.8 & 2.0 & 2.0 & 2.0 \\
\hline & $\begin{array}{l}\% \text { weight } \\
\text { loss/gain }\end{array}$ & -1.4 & 22.5 & 46.2 & 11.9 & 19.0 & 34.7 & 2.2 & 22.5 & 14.1 & 12.9 & 5.4 & 25.5 \\
\hline & stdev & 36.0 & 0.1 & 1.9 & 7.6 & 3.8 & 0.8 & 3.0 & 5.9 & 9.6 & 4.4 & 7.7 & 4.8 \\
\hline
\end{tabular}

CI: condition index, stdev: standard deviation 
Table 3: Multivariate analyses between bioavailable concentrations of organic compounds (hydroxypropyl- $\beta$-cyclodextrin extractions), readily available (methanol extractions), heavy metals and metalloids bioavailable concentrations (pore water and exchangeable fraction), and toxicological response in multiple bioassays performed with Mantel test for dissimilarity matrices.

\begin{tabular}{|c|c|c|c|c|c|c|c|c|c|c|c|c|}
\hline \multirow[t]{2}{*}{ Treatment } & \multirow[t]{2}{*}{ Soil } & \multirow[t]{2}{*}{ Bioassay } & \multicolumn{2}{|c|}{$\begin{array}{c}\text { TPH bioavailable } \\
\text { (hydroxypropyl- } \beta \text {-cyclodextrin) }\end{array}$} & \multicolumn{2}{|c|}{$\begin{array}{c}\text { TPH read.av } \\
\text { (methanol) }\end{array}$} & \multicolumn{2}{|c|}{$\begin{array}{c}\mathrm{HM} \\
\text { Pore water }\end{array}$} & \multicolumn{2}{|c|}{$\begin{array}{c}\mathrm{HM} \\
\text { exchangeable }\end{array}$} & \multicolumn{2}{|c|}{ All } \\
\hline & & & $\mathrm{r}^{2}$ & $p$-value & $\mathrm{r}^{2}$ & p-value & $\mathrm{r}^{2}$ & p-value & $\mathrm{r}^{2}$ & p-value & $r^{2}$ & p-value \\
\hline \multirow{13}{*}{ Compost } & \multirow{7}{*}{ Soil 1} & bact. Count & -0.272 & 0.837 & -0.260 & 0.766 & 0.790 & 0.028 & -0.071 & 0.385 & -0.116 & 0.495 \\
\hline & & soil resp & 0.050 & 0.375 & -0.027 & 0.524 & 0.357 & 0.095 & 0.616 & 0.007 & 0.052 & 0.368 \\
\hline & & PLFAs & 0.386 & 0.090 & 0.289 & 0.217 & -0.104 & 0.608 & 0.287 & 0.123 & 0.309 & 0.186 \\
\hline & & Seeds & 0.789 & 0.008 & 0.635 & 0.030 & 0.141 & 0.267 & -0.105 & 0.712 & 0.752 & 0.009 \\
\hline & & worms & 0.405 & 0.028 & 0.420 & 0.010 & -0.151 & 0.816 & 0.240 & 0.152 & 0.421 & 0.010 \\
\hline & & $\mathrm{EC}_{50}$ & 0.224 & 0.059 & 0.047 & 0.271 & -0.192 & 0.720 & 0.170 & 0.141 & 0.098 & 0.241 \\
\hline & & & & & & & & & & & & \\
\hline & \multirow{6}{*}{ Soil 2} & bact. Count & 0.037 & 0.575 & 0.136 & 0.314 & -0.105 & 0.710 & -0.076 & 0.556 & 0.155 & 0.281 \\
\hline & & soil resp & -0.065 & 0.630 & 0.203 & 0.217 & -0.028 & 0.535 & -0.087 & 0.632 & 0.159 & 0.240 \\
\hline & & PLFAs & -0.353 & 0.729 & 0.171 & 0.363 & 0.046 & 0.189 & -0.124 & 0.477 & -0.211 & 0.460 \\
\hline & & Seeds & 0.042 & 0.583 & 0.271 & 0.167 & 0.204 & 0.083 & 0.374 & 0.229 & 0.338 & 0.104 \\
\hline & & worms & 0.214 & 0.333 & -0.050 & 0.611 & 0.120 & 0.250 & -0.036 & 0.604 & 0.349 & 0.094 \\
\hline & & $\mathrm{EC}_{50}$ & 0.382 & 0.026 & 0.054 & 0.432 & 0.324 & 0.109 & -0.125 & 0.682 & 0.412 & 0.010 \\
\hline \multirow{9}{*}{ Biochar } & \multirow{6}{*}{ Soil 1} & bact. Count & 0.750 & 0.007 & 0.013 & 0.484 & -0.106 & 0.622 & 0.301 & 0.064 & 0.272 & 0.281 \\
\hline & & soil resp & -0.095 & 0.587 & 0.176 & 0.160 & 0.008 & 0.434 & 0.132 & 0.274 & 0.131 & 0.247 \\
\hline & & PLFAs & 0.096 & 0.313 & 0.236 & 0.224 & 0.144 & 0.248 & 0.015 & 0.467 & 0.217 & 0.236 \\
\hline & & Seeds & 0.775 & 0.017 & 0.176 & 0.222 & -0.157 & 0.740 & 0.471 & 0.045 & 0.480 & 0.003 \\
\hline & & worms & n.a & $\mathrm{n} . \mathrm{a}$ & n.a & n.a & n.a & $\mathrm{n} . \mathrm{a}$ & n.a & n.a & n.a & n.a \\
\hline & & $\mathrm{EC}_{50}$ & 0.257 & 0.099 & 0.159 & 0.184 & 0.290 & 0.108 & 0.130 & 0.250 & 0.247 & 0.115 \\
\hline & \multirow{3}{*}{ Soil 2} & bact. Count & -0.140 & 0.384 & 0.591 & 0.014 & 0.871 & 0.049 & 0.328 & 0.314 & 0.387 & 0.019 \\
\hline & & soil resp & -0.020 & 0.526 & 0.454 & 0.007 & 0.245 & 0.130 & 0.209 & 0.139 & 0.553 & 0.012 \\
\hline & & PLFAs & -0.011 & 0.821 & 0.003 & 0.436 & -0.278 & 0.868 & -0.081 & 0.349 & -0.076 & 0.833 \\
\hline
\end{tabular}




\begin{tabular}{|c|c|c|c|c|c|c|c|c|c|c|c|c|}
\hline & & Seeds & 0.050 & 0.972 & 0.153 & 0.175 & -0.202 & 0.679 & -0.305 & 0.622 & 0.073 & 0.689 \\
\hline & & worms & 0.224 & 0.510 & 0.153 & 0.175 & 0.088 & 0.094 & -0.185 & 0.500 & 0.151 & 0.396 \\
\hline & & $\mathrm{EC}_{50}$ & 0.320 & 0.045 & 0.211 & 0.201 & 0.759 & 0.005 & -0.120 & 0.738 & 0.510 & 0.019 \\
\hline \multirow{12}{*}{$\begin{array}{c}\text { Un- } \\
\text { amended }\end{array}$} & \multirow{6}{*}{ Soil 1} & bact. Count & 0.109 & 0.306 & -0.118 & 0.606 & 0.521 & 0.023 & 0.061 & 0.411 & 0.062 & 0.363 \\
\hline & & soil resp & 0.203 & 0.104 & 0.449 & 0.003 & 0.117 & 0.231 & 0.199 & 0.106 & 0.449 & 0.002 \\
\hline & & PLFAs & 0.247 & 0.167 & 0.497 & 0.017 & -0.247 & 0.892 & 0.185 & 0.220 & 0.428 & 0.036 \\
\hline & & Seeds & 0.279 & 0.193 & 0.333 & 0.080 & 0.039 & 0.392 & 0.693 & 0.007 & 0.320 & 0.064 \\
\hline & & worms & n.a & n.a & n.a & n.a & n.a & n.a & n.a & n.a & n.a & $\mathrm{n} . \mathrm{a}$ \\
\hline & & $\mathrm{EC}_{50}$ & -0.149 & 0.833 & 0.127 & 0.149 & -0.019 & 0.563 & 0.276 & 0.063 & -0.045 & 0.594 \\
\hline & \multirow{6}{*}{ Soil 2} & bact. Count & -0.279 & 0.955 & 0.502 & 0.052 & 0.005 & 0.524 & 0.003 & 0.488 & 0.115 & 0.307 \\
\hline & & soil resp & -0.293 & 0.873 & 0.511 & 0.050 & 0.015 & 0.333 & -0.376 & 0.917 & 0.148 & 0.149 \\
\hline & & PLFAs & -0.229 & 0.892 & 0.589 & 0.026 & 0.125 & 0.253 & -0.100 & 0.597 & 0.347 & 0.076 \\
\hline & & Seeds & -0.068 & 0.576 & -0.169 & 0.701 & 0.478 & 0.021 & -0.356 & 0.972 & 0.001 & 0.465 \\
\hline & & worms & -0.057 & 0.635 & 0.378 & 0.165 & 0.265 & 0.146 & -0.254 & 0.747 & 0.371 & 0.146 \\
\hline & & $\mathrm{EC}_{50}$ & 0.123 & 0.236 & 0.284 & 0.042 & 0.764 & 0.038 & 0.150 & 0.226 & 0.466 & 0.010 \\
\hline
\end{tabular}

TPH: total petroleum hydrocarbons, HM: heavy metals (and metalloids), all: bioavailable measures combined (bio., readav., pw., ex.),

bact count: bacteria count (CFU), soil resp: respiration $\left(\mathrm{mg} \mathrm{CO}_{2} / \mathrm{g}\right.$ soil), PLFAs: phospholipid fatty acids analysis, seeds: seed germination assay

(\% germinated/total), worms: earthworm acute toxicity assay (Condition Index), $\mathrm{EC}_{50}$ : Microtox ${ }^{\circledR} \mathrm{EC}_{50}$ values.

Statistically significant at $\mathrm{p}$-value $>0.05$ 
Figures- Linking bioavailability and toxicity changes of complex chemicals mixture to inform the recovery and end point of remediation of contaminated soils-Cipullo et al.

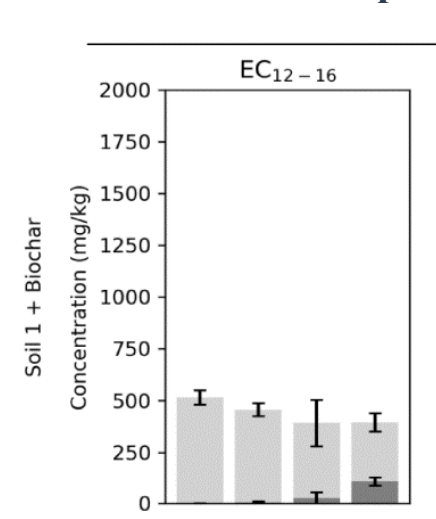

$$
\text { Aromatics }
$$
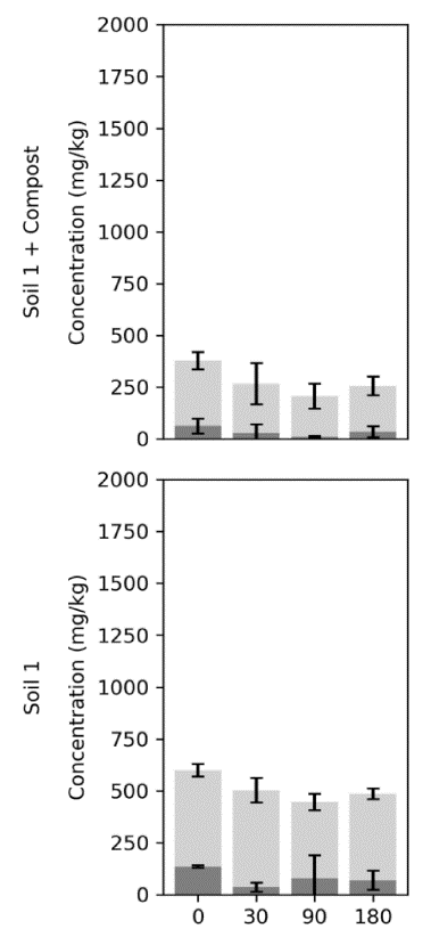
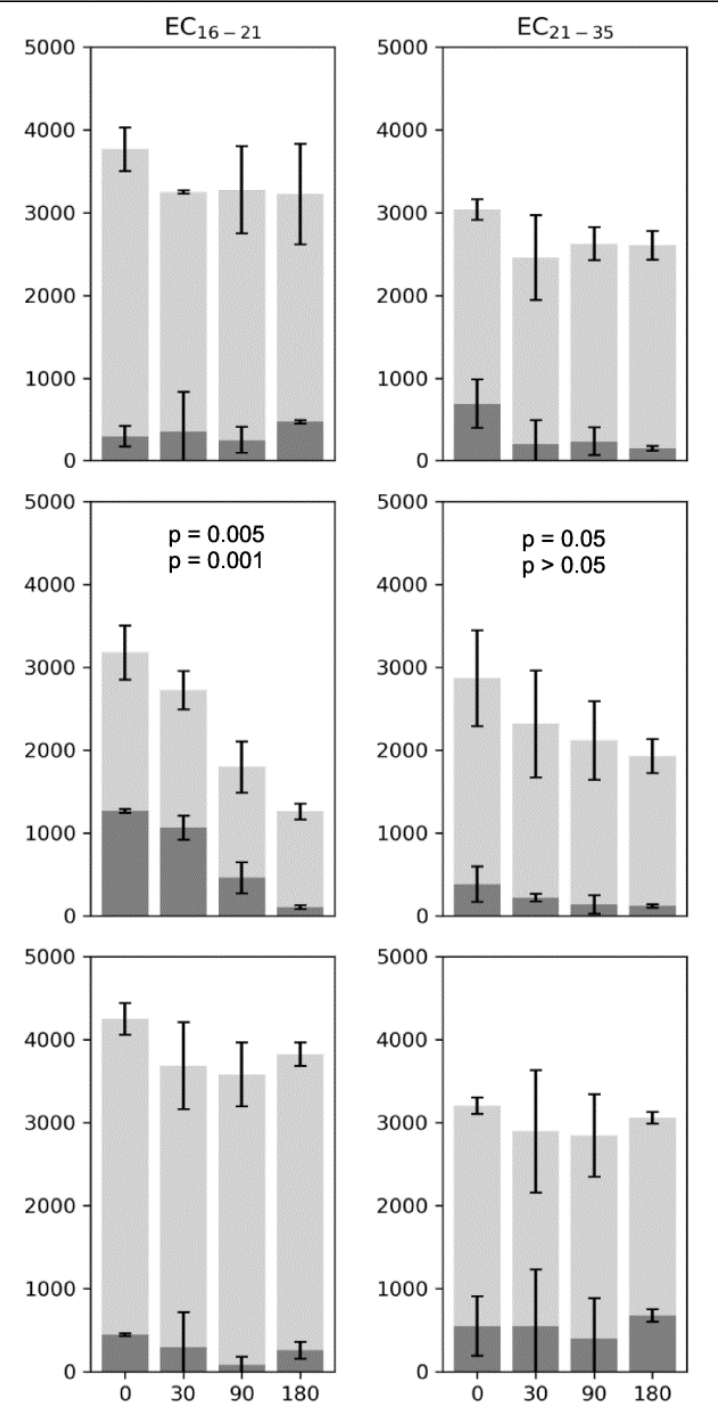
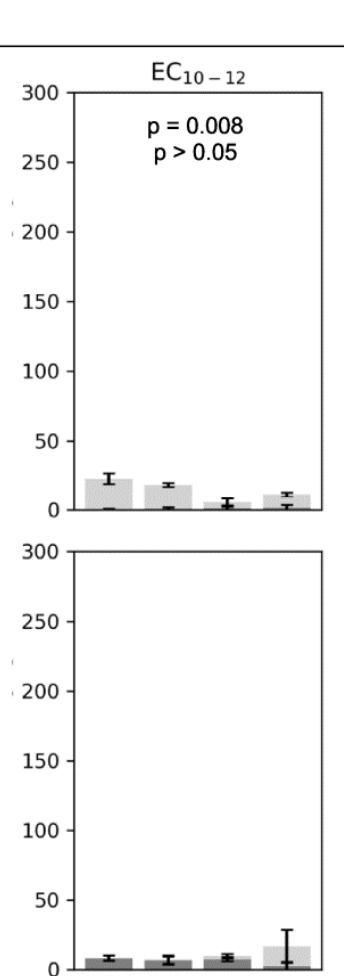

Aliphatics
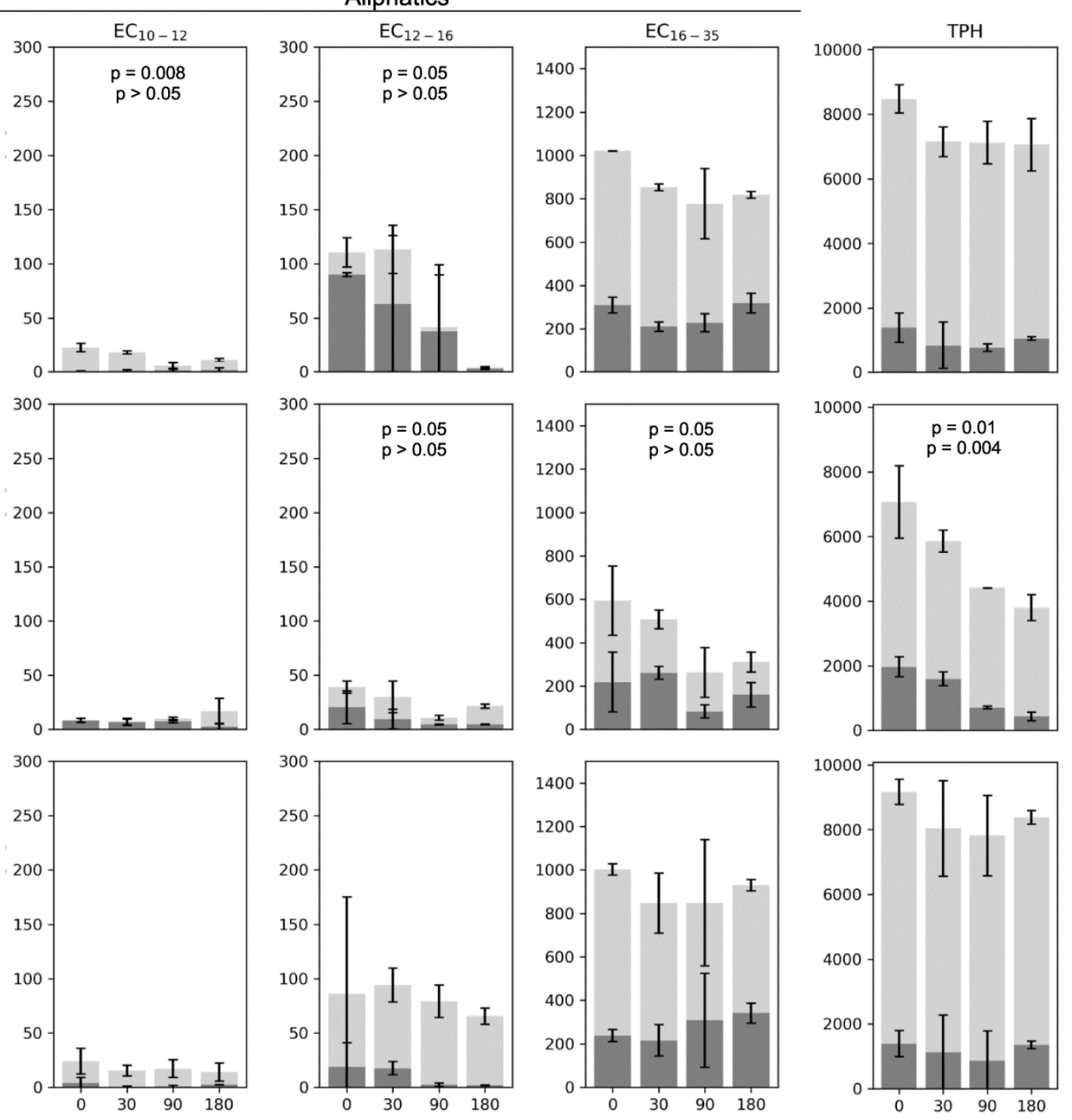

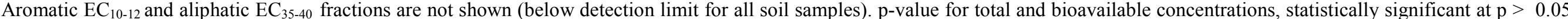
(ANOVA test). Error bars correspond to the standard deviation across replicates for each grouped compounds. 
Figure 1: Soil 1, total (light grey) and bioavailable from hydroxypropyl- $\beta$-cyclodextrin extraction (dark grey) concentrations (expressed in $\mathrm{mg} / \mathrm{kg}$ ) of aromatics $\left(\mathrm{EC}_{12-16}, \mathrm{EC}_{16-21}\right.$, and $\left.\mathrm{EC}_{21-35}\right)$ and aliphatics $\left(\mathrm{EC}_{10-12}, \mathrm{EC}_{12-16}\right.$, and $\left.\mathrm{EC}_{16-35}\right)$ across the sampling time (0, 30, 90, and 180 days).

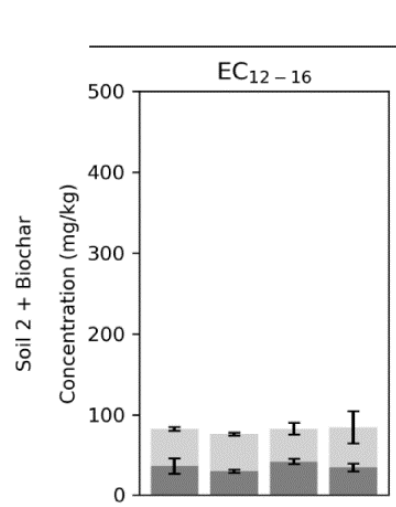

Aromatics
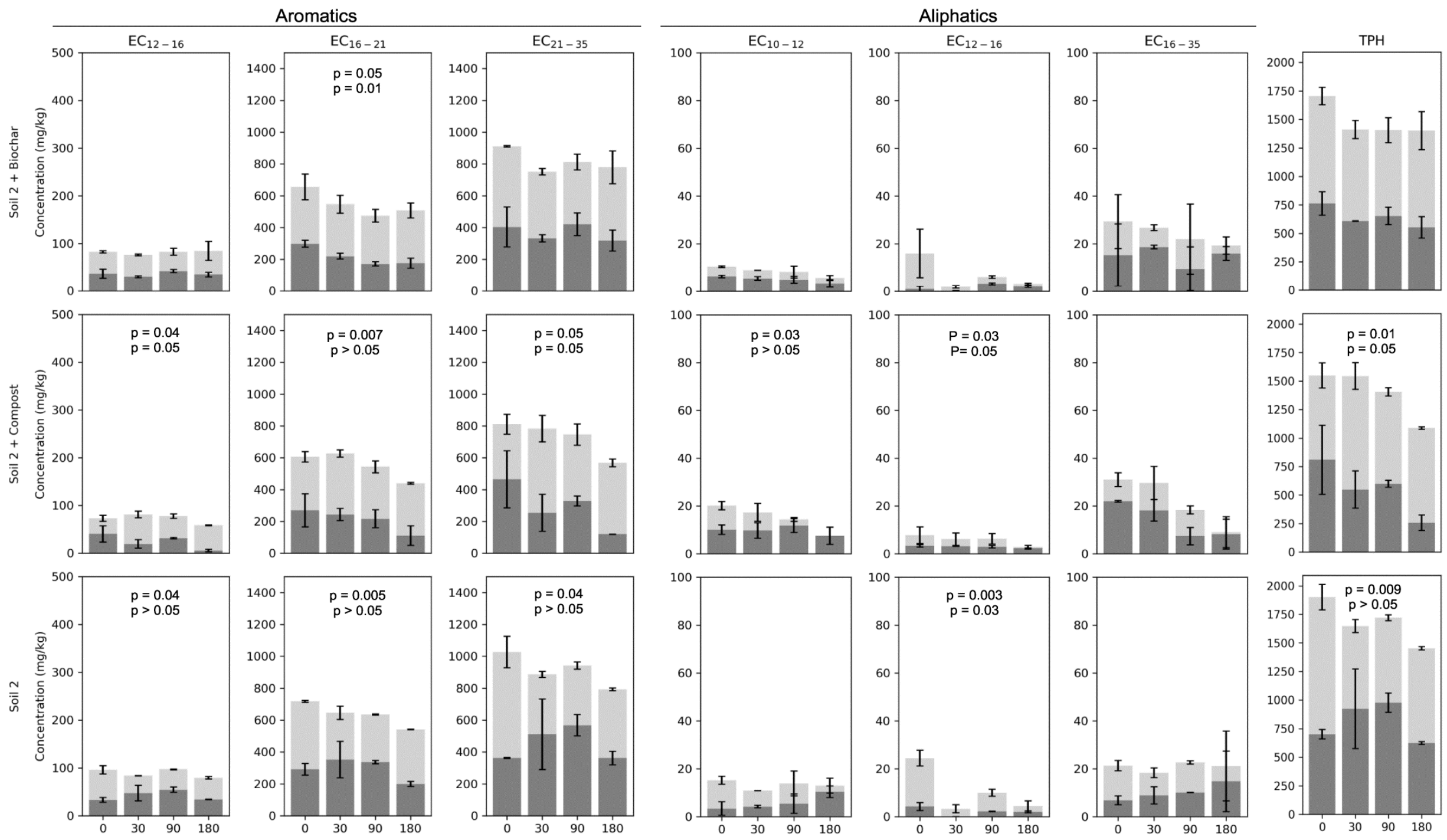

Figure 2: Soil 2, total (light grey) and bioavailable from hydroxypropyl- $\beta$-cyclodextrin extraction (dark grey) concentrations (expressed in mg/kg) of aromatics $\left(\mathrm{EC}_{12-16}, \mathrm{EC}_{16-21}\right.$, and $\left.\mathrm{EC}_{21-35}\right)$ and aliphatics $\left(\mathrm{EC}_{10-12}, \mathrm{EC}_{12-16}\right.$, and $\left.\mathrm{EC}_{16-35}\right)$ across the sampling time (0, 30, 90 , and 180 days). Aromatic $\mathrm{EC}_{10-12}$ and aliphatic $\mathrm{EC}_{35-40}$ fractions are not shown (below detection limit for all soil samples). p-value for total and bioavailable concentrations, statistically significant at $\mathrm{p}>0.05$ (ANOVA test) Error bars correspond to the standard deviation across replicates for each grouped compounds. 

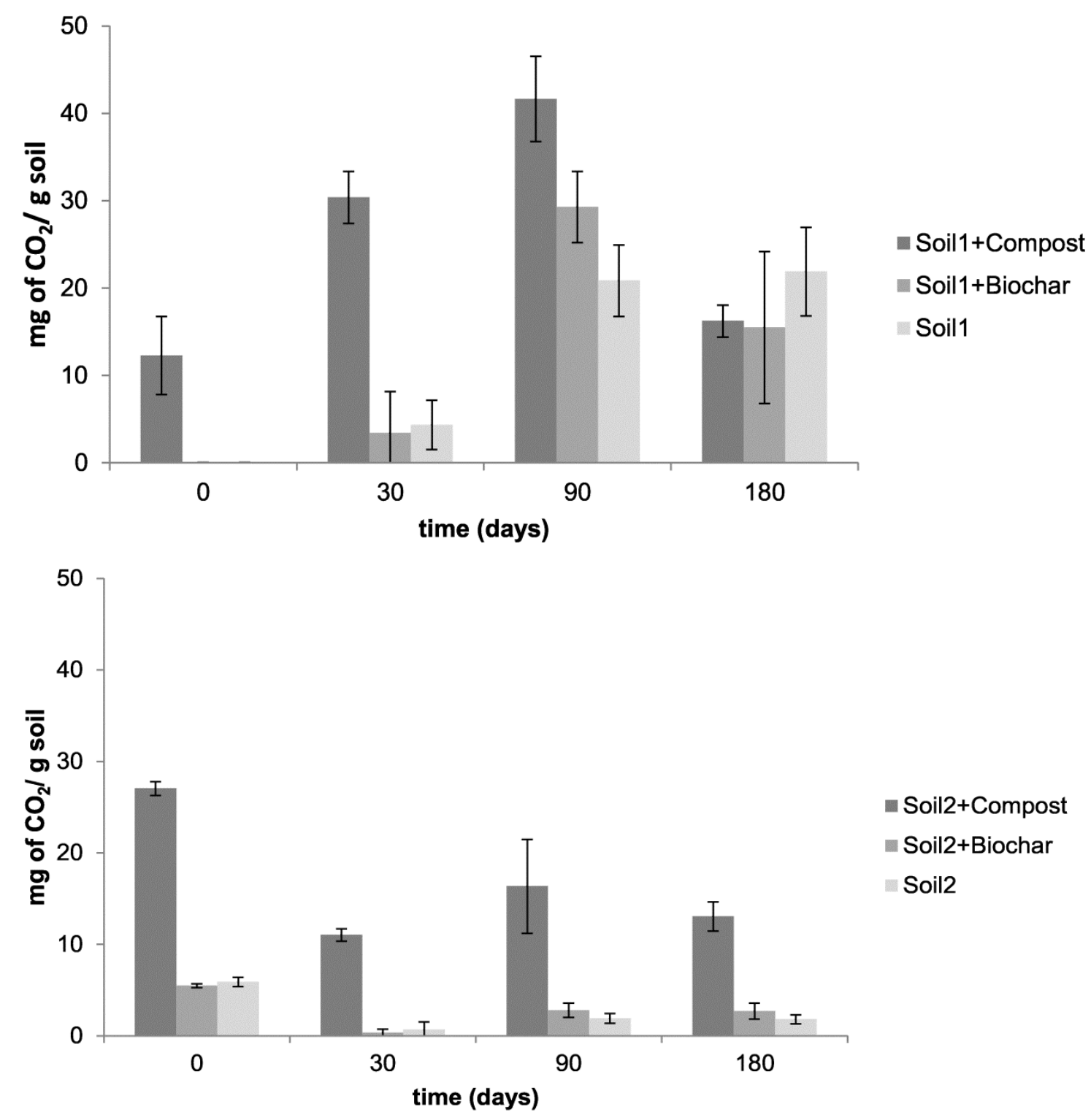

Figure 3: Soil respiration expressed as $\mathrm{CO}_{2}$ production $(\mathrm{mg} \mathrm{CO} / \mathrm{g}$ soil) for treated with compost, biochar, or un-amended (Soil 1 and Soil 2), tested at 0, 30, 90 and 180 days. Error bars correspond to the standard deviation across replicates. 

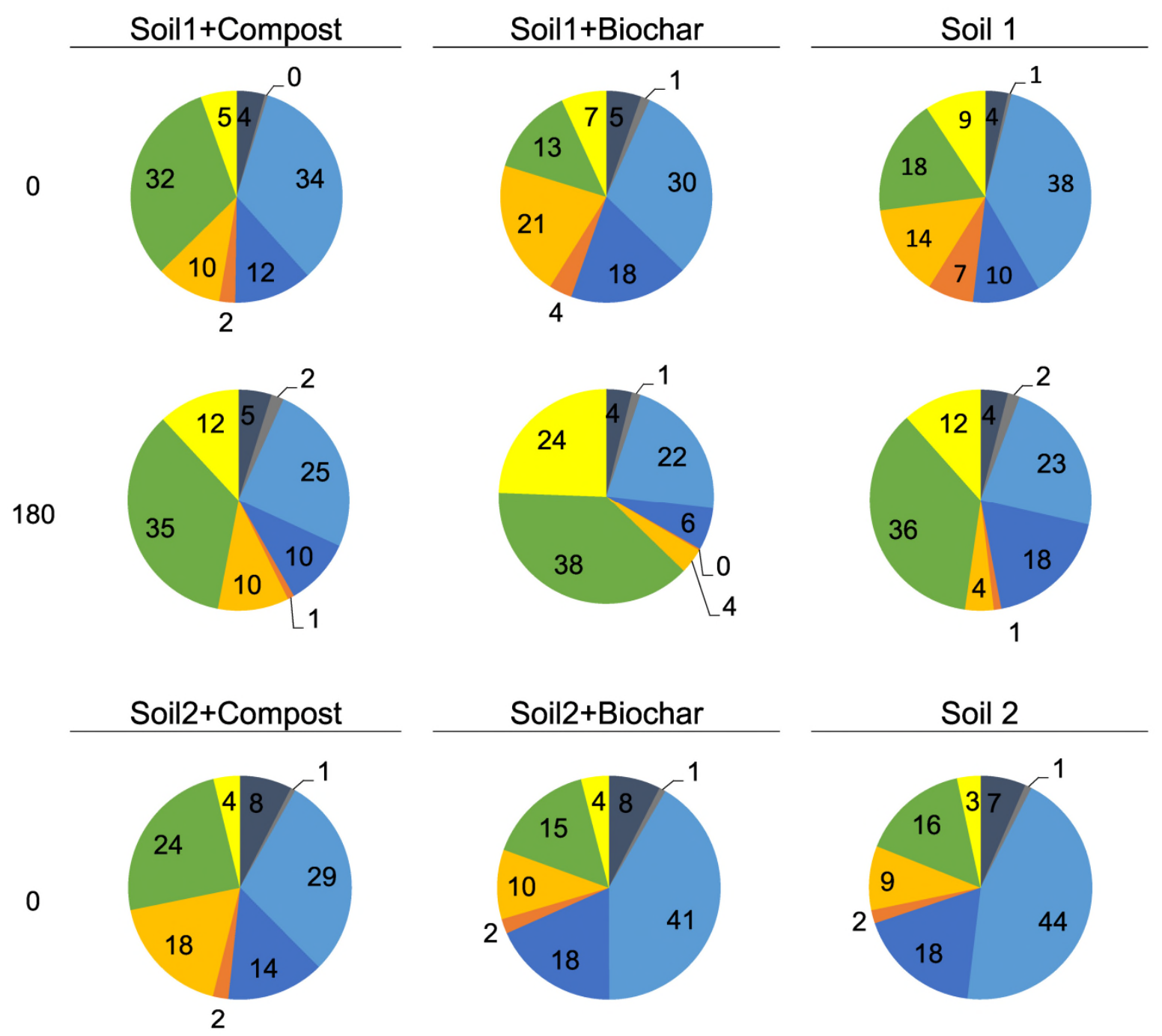

Soil 2
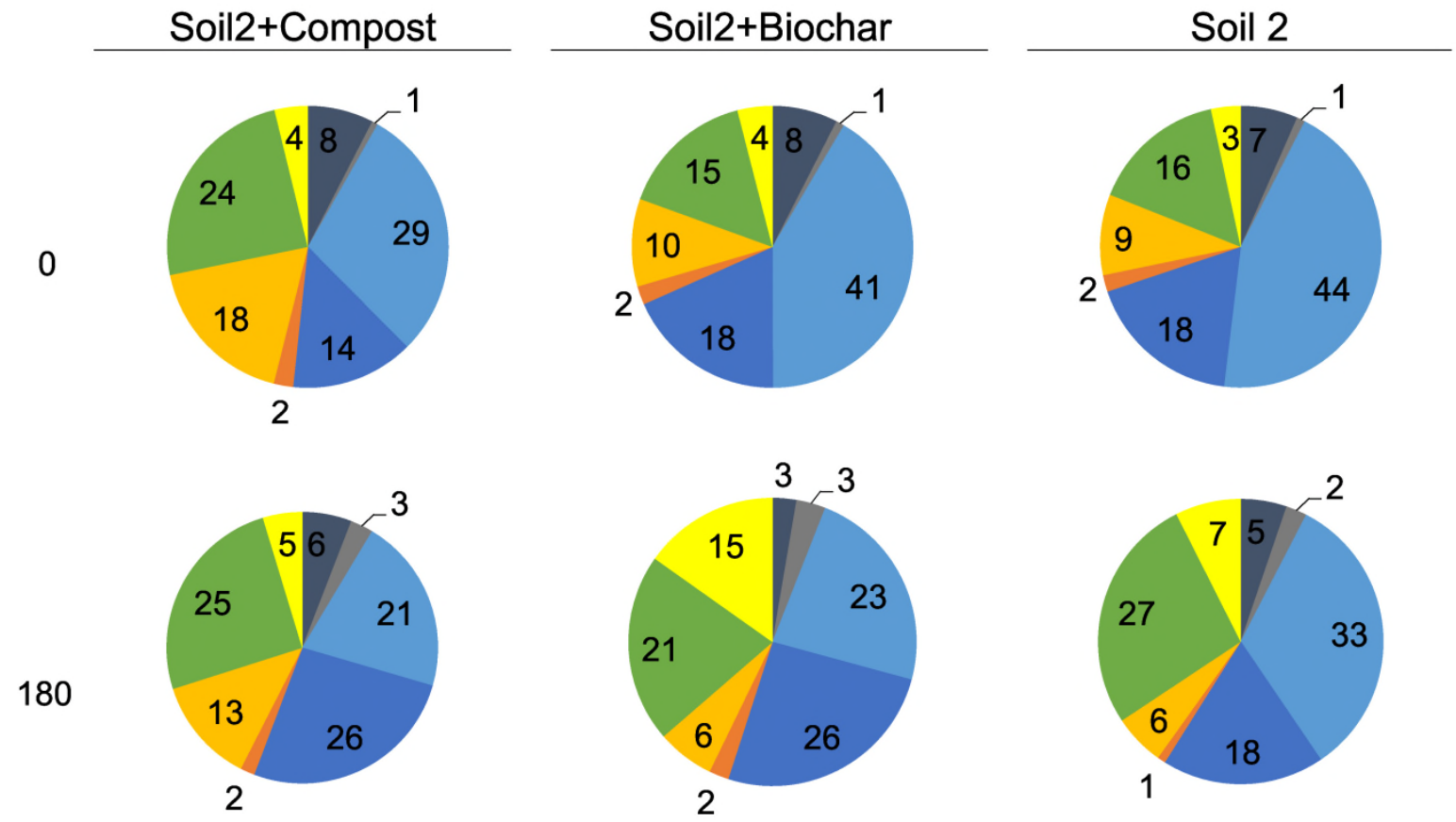

$$
\begin{aligned}
& \text { - Bacillus or Arthrobacter Cianobacteria, diatoms } \\
& \text {-Fungi } \quad \text { Fungi/Gram-positive } \\
& \text { - General bacteria } \quad \text { Gram-negative } \\
& \text { - gram-positive } \quad \text { Other }
\end{aligned}
$$

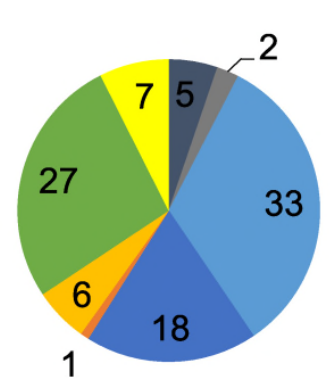

Figure 4: Classification of PLFA identified treated with compost, biochar, or un-amended (Soil 1 and Soil 2) comparing onset (0 days) and end of incubation period (180 days). The relative abundance of individual PLFA was expressed as a percentage of the total of the target responses. 

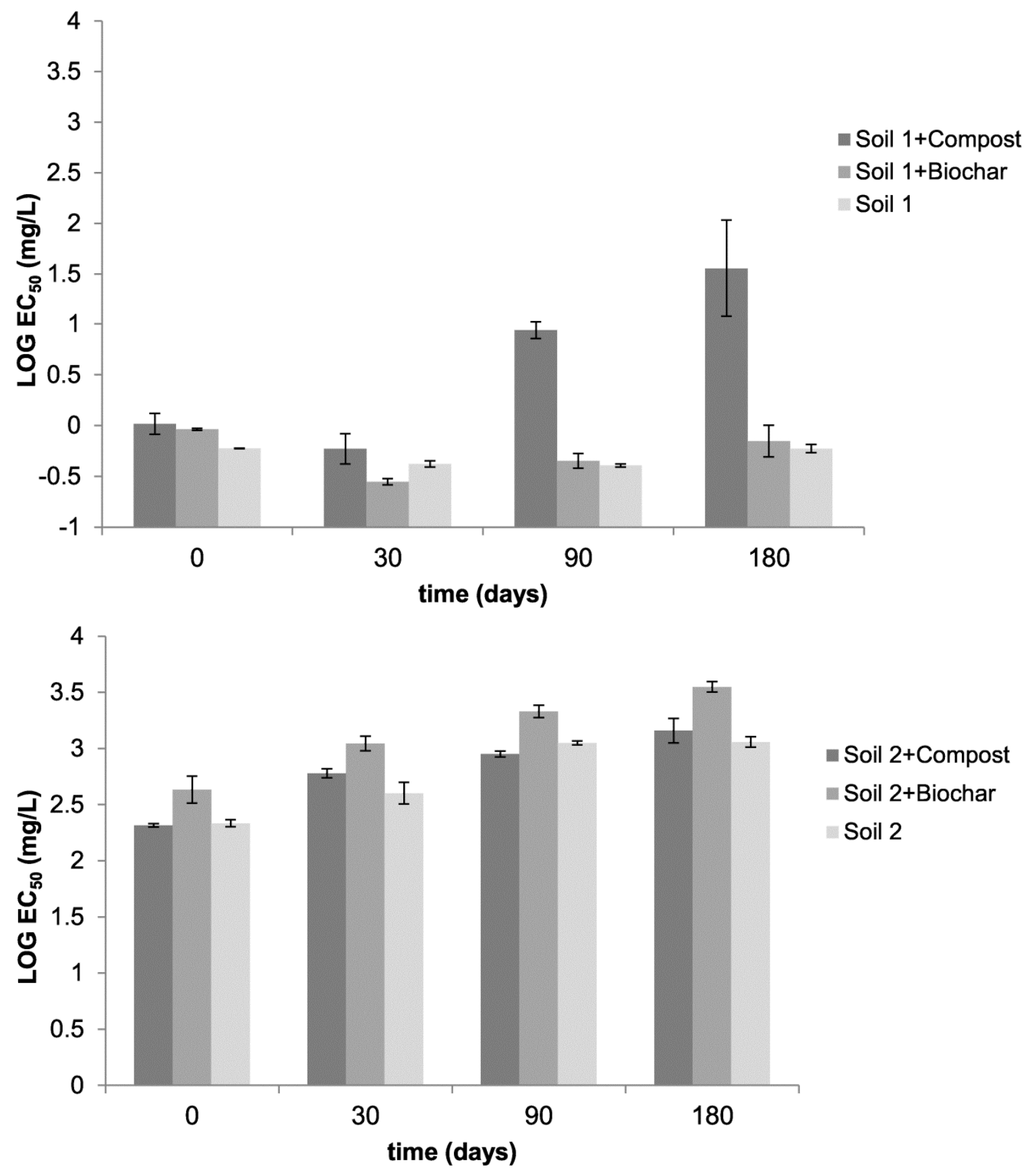

Figure 5: Microtox ${ }^{\circledR}$ Basic Solid phase Test (BSPT) assay average results expressed as Log of $\mathrm{EC}_{50}$ concentration $(\mathrm{mg} / \mathrm{L})$ for light decrease values at the onset and after 30, 90, and 180 days for treated with compost, biochar, or un-amended (Soil 1 and Soil 2). Error bars indicate standard error of the repeated measures (toxicity decreases when the $\mathrm{EC}_{50}$ value increases). 


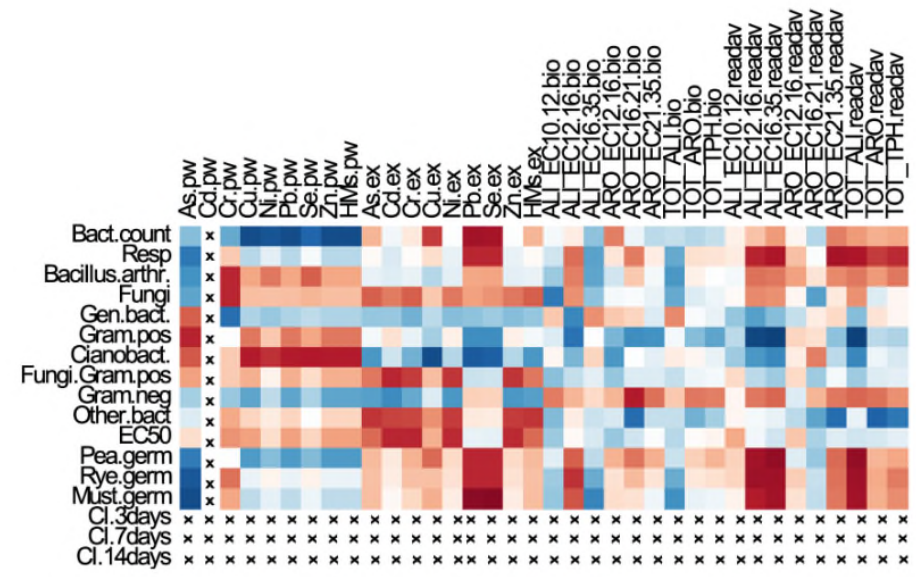

(a)

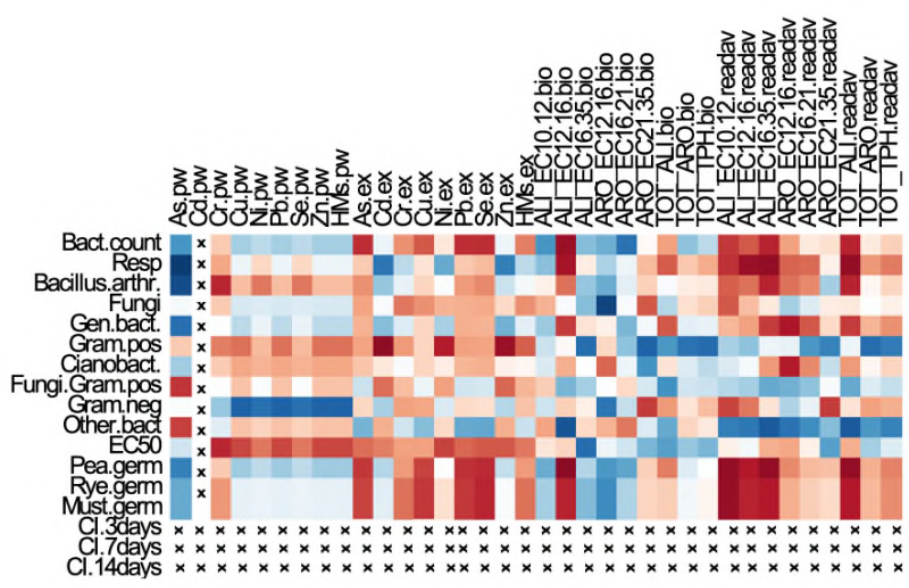

(b)

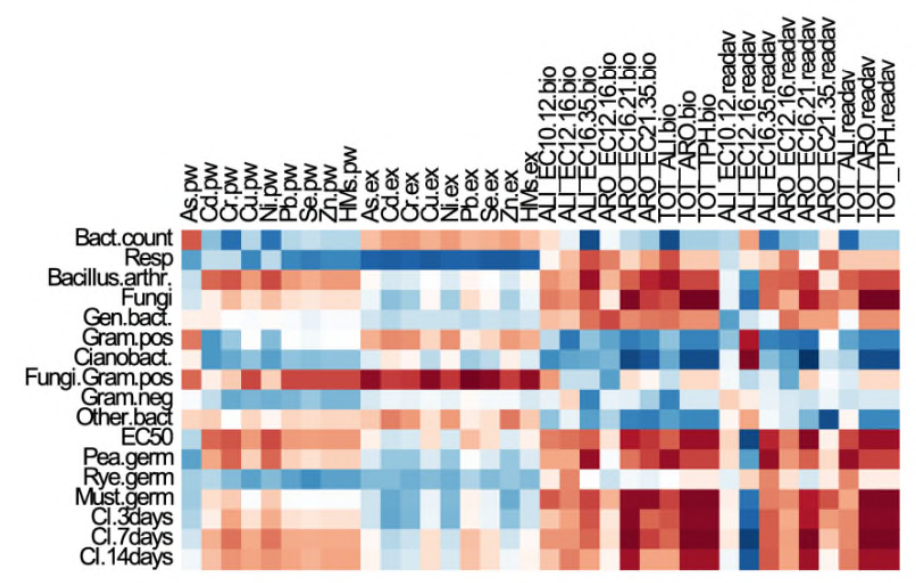

(c)

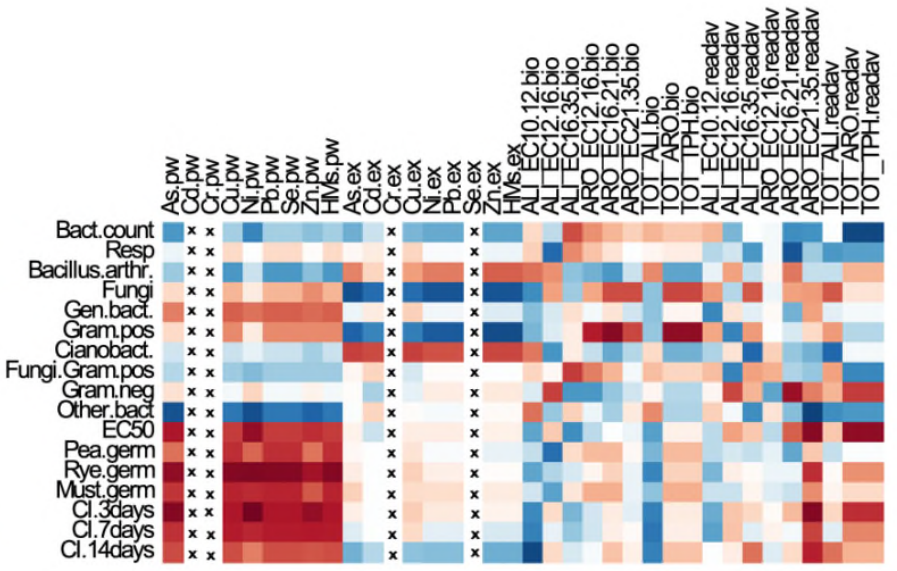

(d)

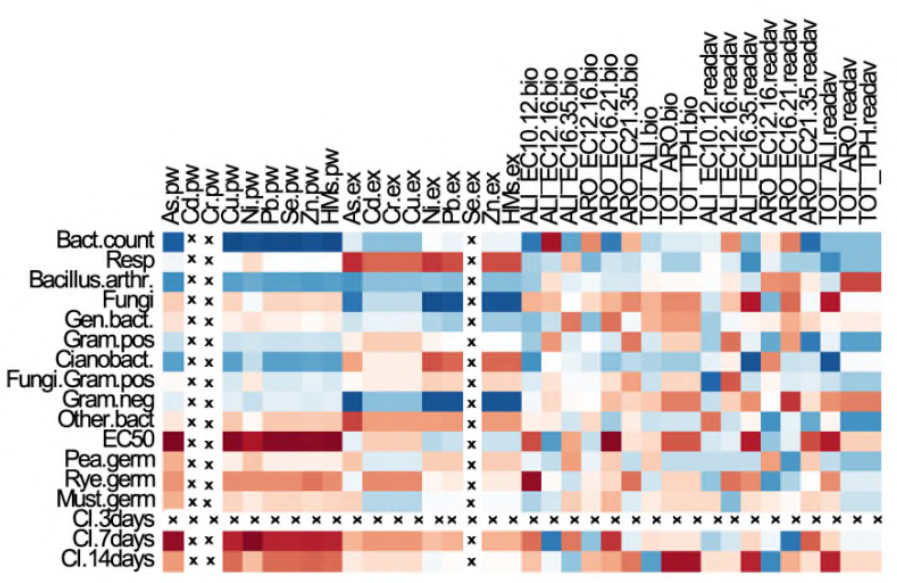

(e)

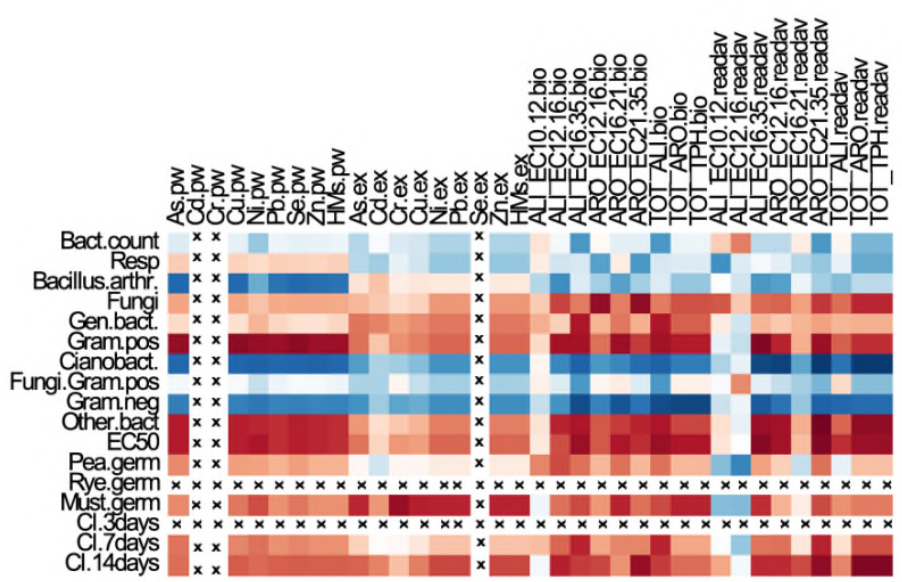

(f)

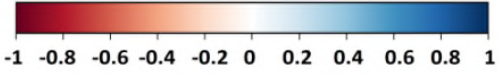

Figure 6: Linear correlation (based on Spearman coefficient) between organic and inorganic bioavailable concentrations and toxicological responses in multiple bioassays. Soil 1 (a), Soil 1+ Biochar (b), Soil $1+$ Compost (c), Soil 2 (d), Soil $2+$ Biochar (e), and Soil $2+$ Compost (f). Positive correlations were displayed in blue and negative correlations in red colour, were intensity were proportional to the correlation coefficients (scale). $\mathrm{x}$ rows $=$ all values equal, no 
correlation; $\mathrm{x}$ columns $=$ all values below detection limits; Pw: Pore Water, Ex: Exchangeable, ALI: Aliphatics hydrocarbons, ARO: Aromatics hydrocarbons, R: Aromatic Bio: Bioavailable, Readav: Readily Available, Bact.Count: Bacteria Count, Resp: Respiration, Bacillus.Arthr. : Bacillus Or Arthrobacter, Gen.Bac :General Bacteria, Gram.Pos: Gram Positive, Cianobact: Cyanobacteria, Gram Neg.: Gram Negative, Other Bac: Other Bacteria, $\mathrm{EC}_{50}$ : Microtox ${ }^{\circledR} \mathrm{EC}_{50}$ Values, Germ: Germination, CI: Condition Index(at 3,7, and 14 days). 